\title{
Sperm DNA Integrity and Male Fertility in Farm Animals: A Review
}

\author{
Arumugam Kumaresan ${ }^{1 *}$, Mohua Das Gupta ${ }^{1}$, Tirtha Kumar Datta ${ }^{2}$ and Jane M. Morrell ${ }^{3}$ \\ ${ }^{1}$ Theriogenology Laboratory, Southern Regional Station of National Dairy Research Institute (ICAR), Bengaluru, India, ${ }^{2}$ Animal \\ Genomics Laboratory, National Dairy Research Institute (ICAR), Karnal, India, ${ }^{3}$ Department of Clinical Sciences, Swedish \\ University of Agricultural Sciences, Uppsala, Sweden
}

\section{OPEN ACCESS}

Edited by:

Fernando J. Peña Vega,

University of Extremadura, Spain

Reviewed by:

Jose Manuel Ortiz-Rodriguez,

University of Extremadura, Spain

Gemma Gaitskell-Phillips,

University of Extremadura, Spain

Manuel Hidalgo,

Universidad de Córdoba, Spain

${ }^{*}$ Correspondence:

Arumugam Kumaresan

a.kumaresan@icar.gov.in;

ogkumaresan@gmail.com

Specialty section:

This article was submitted to

Animal Reproduction -

Theriogenology,

a section of the journal

Frontiers in Veterinary Science

Received: 06 April 2020

Accepted: 11 May 2020

Published: 19 June 2020

Citation:

Kumaresan A, Das Gupta M, Datta TK and Morrell JM (2020) Sperm DNA Integrity and Male Fertility in Farm Animals: A Review.

Front. Vet. Sci. 7:321. doi: 10.3389/fvets.2020.00321
The accurate prediction of male fertility is of major economic importance in the animal breeding industry. However, the results of conventional semen analysis do not always correlate with field fertility outcomes. There is evidence to indicate that mammalian fertilization and subsequent embryo development depend, in part, on the inherent integrity of the sperm DNA. Understanding the complex packaging of mammalian sperm chromatin and assessment of DNA integrity could potentially provide a benchmark in clinical infertility. In the era of assisted reproduction, especially when in-vitro fertilization or gamete intrafallopian transfer or intracytoplasmic sperm injection is used, assessment of sperm DNA integrity is important because spermatozoa are not subjected to the selection process occurring naturally in the female reproductive tract. Although sperm DNA integrity testing measures a significant biological parameter, its precise role in the infertility evaluation in farm animals remains unclear. In this review, the earlier findings on sperm DNA integrity in relation to male fertility are compiled and analyzed. Furthermore, the causes and consequences of sperm DNA damage are described, together with a review of advances in methods for detection of sperm DNA damage, and the prognostic value of sperm DNA quality on male fertility.

Keywords: male infertility, sperm, DNA integrity, epigenetic modifications, prognostic value

\section{INTRODUCTION}

Infertility has been a concern throughout the ages and is still a significant problem in several species, including human beings, and farm animals. In spite of several advancements in diagnostic techniques and infertility treatments, the levels of infertility in the human population were similar in 1990 and 2010, with only a slight overall decrease in primary infertility (0.1\%) and a modest overall increase in secondary infertility $(0.4 \%)(1)$. Although such large-scale studies are very limited in farm animals, existing information indicates that subfertility is rising in livestock, which can have adverse effects on animal welfare and farm economy by delayed calving intervals and increased culling of animals. Dobson et al. (2) reported that, over the past 30 to 50 years, the first-service-pregnancy-rate in dairy cattle dropped from 70 to $40 \%$. Intrinsically, both male and female contribute to infertility, but male factor infertility accounts for $40-50 \%$ of infertility (3). In crossbred bulls, it was reported that the "acceptable quality semen producing ability" decreased, over a period, from grandsire through sire to male progeny (4). The significance of male fertility is highly amplified in farm animals since semen from a male is used for artificial insemination in several thousand females, and use of semen from infertile bulls affects conception, leading to considerable losses for farmers. 
Male infertility refers to a male's inability to achieve pregnancy in a fertile female. In human beings, it was observed that male factor alone is responsible for $\sim 26 \%$ of infertility cases (5) and contributory in another $30-40 \%$ of infertile couples (6). Several causes have been attributed to male infertility including genetic disorders, hormonal disturbances, disorders in spermatogenesis, poor sperm quality and sperm DNA fragmentation $(6,7)$. In the last few decades, there has been an increasing body of research investigating the role of sperm DNA integrity in male factor infertility (8). Evidence is accumulating that DNA damage is greater in spermatozoa of infertile males compared to fertile males (9-12). In dairy bulls, it was reported that DNA damage accounted for significant variations in fertility and the proportion of spermatozoa with DNA damage was more than 2-fold higher in below-average fertility bulls compared to aboveaverage fertility bulls (13). Very recently, Boe-Hansen et al. (14) also confirmed the role of sperm DNA integrity in bull fertility and suggested that the presence of immature spermatogenic cells, cytoplasmic proximal droplets and alterations in sperm head shape were associated with sperm DNA integrity and protamine deficiency. Similar reports on the role of sperm DNA integrity in fertility and/or semen quality are available for other farm animals, including stallion $(15,16)$, boar (17-19), and $\operatorname{ram}(20,21)$. Interestingly, sperm DNA integrity in relation to male fertility has become a hot topic recently. A search using the keywords "sperm DNA integrity and fertility" in PubMed showed 5,700 publications on this subject between 2005 and 2019, in contrast to only 251 publications between 1990 and 2004. On the other hand, despite the higher number of publications, there is no consensus on whether measurement of sperm DNA damage provides any clinical benefit in the assessment of male infertility (22).

In this review, previous findings on sperm DNA integrity in relation to male fertility are compiled and analyzed. Furthermore, the causes and consequences of sperm DNA damage are described, together with a review of advances in methods for detection of sperm DNA damage, and the prognostic value of sperm DNA quality on male fertility is also discussed.

\section{SPERM DNA INTEGRITY AND CAUSES OF DAMAGE}

Since the findings of Alfert (23), that histone is replaced by protamine during spermiogenesis in salmon, research on sperm DNA integrity and fragmentation in relation to fertility increased rapidly. The pioneering work of Evenson et al. (24) on the relationship of DNA integrity and pregnancy outcome showed the existence of significant variations in sperm DNA integrity among individual males. Intact DNA is defined as the complete absence of nicks or breaks, either single or doublestranded, or any chemical modifications in its structure (25). Generally, most of the affected spermatozoa are phagocytosed by Sertoli cells or undergo programmed cell death by a caspasedependent apoptosis pathway without releasing any harmful substances $(26,27)$. Despite this safety mechanism, sperm DNA damage occurs, which might be due to the liberation of substances such as reactive oxygen species (ROS), amongst others, from the dead spermatozoa. However, the findings of several researchers confirmed two possible causes of damage: one during spermatogenesis, due to impaired chromatin maturation, and the other during spermiogenesis, at the time of histone replacement by protamine followed by further compaction of DNA during epididymal transits $(28,29)$. Most of the damage is premutagenic and could be a result of either intrinsic or extrinsic factors.

\section{INTRINSIC FACTORS}

\section{Insufficiency in Recombination During Spermatogenesis}

Usually, in a homologous pair of chromosomes, crossing over of genetic material during spermatogenesis takes place by activation of specific nucleases, which favors DNA breaks/damage. Thus, any kind of aberration in the recombination process can lead to cell death e.g., DNA-DNA and DNA-Protein cross-linking occur in the highly compact chromatin of mammalian germ cell rather than in somatic cells and is more commonly seen in defective spermatozoa (30).

\section{Reactive Oxygen Species}

Reactive oxygen species (ROS) are highly reactive and retain the capacity to damage any cell structure or function. They are produced in both fertile and infertile individuals and have positive as well as negative effects. Their production in semen is controlled by both the spermatozoa and the seminal plasma antioxidant defense system. Spermatozoa possess low intra-cellular antioxidant activity consisting of superoxide dismutase, glutathione peroxidase, peroxiredoxin, thioredoxin, thioredoxin reductase etc., depending on the species. In stallions, spermatozoa also have intrinsic antioxidant defenses, such as glutathione and various enzymes such as paraoxonase, thioredoxin and the peroxidation families of proteins (31). Pathogenic effects are observed when the production of ROS exceeds the capacity of the antioxidant defense system to neutralize them or there is infiltration of leukocytes (32). Excessive levels of ROS coupled with a deficiency in antioxidants can lead to oxidative stress resulting in nuclear and mitochondrial DNA damage, telomere shortening, epigenetic alterations and $\mathrm{Y}$ chromosomal microdeletions (33). Bovine sperm DNA integrity is affected by excessive exposure to ROS, obliterating DNA compaction or the repair of double- or singlestranded breaks during the reconfiguration of DNA, as occurs in cryopreservation of semen samples $(34,35)$. A single-strand break is the outcome of an oxidative attack, whereas a doublestrand break is the indirect consequence of the products of lipid peroxidation e.g., 4- hydroxyl-2-nonenal (36).

\section{Abortive Apoptosis}

DNA damage due to apoptosis mainly occurs in the testis during spermatogenesis. Apoptosis controls the overproduction of spermatozoa and restricts the proliferation level during unfavorable conditions for sperm development. The presence of apoptotic markers in mature sperm, including Fas, Bcl-X, p53, and annexin $\mathrm{V}$ all support the role of apoptosis in the generation 
of DNA breaks (37). However, the relationship between the presence of these typical markers of apoptosis in spermatozoa and the degree of DNA fragmentation is not straightforward. It is reported that the routes for sperm DNA fragmentation and cell death are not fully caspase dependent (38). Abortive apoptosis is a phenomenon where the defective sperm cell escapes programmed cell death and is present in the ejaculate. However, these defective sperm cells with partial DNA breaks retain their fertilizing potential but lack the ability to support pregnancy, resulting in early embryonic loss $(39,40)$.

\section{Endogenous Nuclease}

During spermatogenesis, endogenous nuclease (topoisomerase II) is activated, relieving torsional stress of highly compacted chromatin packaging in immature spermatids. The replacement of $85-95 \%$ of the histones by transitional proteins and eventually by Protamine 1 and 2 occurs, resulting in further condensation of chromatin materials and cessation of transcription and translation (41). However, during this replacement process, endogenous nucleases (topoisomerase II) create and ligate nicks, with the result that the majority of the damage is repaired during epididymal transit. Sometimes nicks in sperm chromatin escape this repair mechanism, with the result that spermatozoa with damaged chromatin appear in the ejaculate, indicating aberrant spermatogenesis and incomplete maturation. Normally, the ratio of protamine 1 to total protamine in spermatozoa varies widely among species; 0 for bull, 0.14 for stallion, 0.34 for hamster, 0.43 for human, and 0.67 for mouse (42). On the other hand, the relative proportion of sperm protamine 1 to sperm protamine 2 is nearly similar, with a ratio of 1:1 in human, bull, stallion, boar, and rodents. However, any alteration in this ratio is associated with DNA fragmentation, poor fertilization and reduced conception rate (43).

\section{EXTRINSIC FACTORS}

\section{Age}

While a few studies suggest that sperm DNA integrity is not affected by age $(44,45)$, other studies demonstrate a significant increase in sperm DNA damage with age $(46,47)$. In contrast, Fortes et al. (48) found that younger bulls had higher DNA fragmentation indices compared to adult animals. In Nellore bulls, it was reported that young bulls (1.8-2 years) and aged bulls (8-14.3 years) were found to be more susceptible to DNA damage compared to adult bulls (3.5-7 years), with young bulls exhibiting more defective protamination than older animals and aged bulls showing more nuclear oxidative damage (49).

\section{Increased Testicular Temperature}

Sperm DNA fragmentation was also reported to increase with increase in testicular temperature. Basically, maintaining scrotal surface temperature at $2-6^{\circ} \mathrm{C}$ lower than core body temperature is a prerequisite for normal spermatogenesis. Elevation of testicular temperature increased testicular metabolism and altered the hormonal profile, with concomitant rise in oxygen demand to sustain aerobic metabolism, resulting in tissue hypoxia, generation of reactive oxygen species, and deterioration of semen quality (50). Production of excessive ROS causes major damage to sperm DNA integrity (51). Several researchers observed a decrease in sperm count, sperm motility, normal morphology and increase in sperm DNA damage due to increase in thermal stress and environmental pollution in bull, horse, goat, human, mouse $(52,53)$.

\section{Cryopreservation and Storage Temperature of Sperm Samples}

The effect of storage temperature and cryopreservation on sperm DNA have been studied in various species. Basically, temperature shock during cryopreservation are associated with a subsequent increase in oxidative damage to sperm DNA, plasma membranes and a decrease in viability, simultaneously leading to a decline in sperm quality. There is a dramatic increase in DNA fragmentation due to increased production of ROS during cryopreservation and storage of sperm cells for short or long periods of time in bull (54), ram (55), stallion (15), and boar (56). Various studies on sperm DNA fragmentation dynamics before and after sperm storage showed that cryopreservation is an important issue that must be considered since it can decrease DNA longevity $(57,58)$.

\section{Vaccination Stress}

The effect of vaccination on semen quality has been widely studied. In general, vaccination stress causes febrile condition and elevates testicular temperature with a subsequent rise in ROS production. This increase in ROS, causes a deterioration in sperm morphology, antioxidative profiles and sperm DNA (59). In farm animals, it has been shown that vaccination-induced thermal insult resulted in extensive damage to the sperm DNA, reducing the fertilization rate $(59,60)$. Gosálvez et al. (61) also recorded a significant increase in sperm DNA damage after vaccination of rams, but observed that the negative impact was reversible. In another study, Gupta et al. (62) reported a deleterious effect of foot-and-mouth disease vaccine on plasma membrane integrity and morphology of bull sperm.

\section{Sex Sorting of Spermatozoa}

During the recent past, the use of sexed semen for skewing sex ratio increased dramatically, especially in cattle. Some studies indicated that sex sorting does not affect the quality of sperm DNA in species such as deer (63) and boar (64). However, another study reported that although DNA fragmentation immediately after thawing was higher in conventional than in sex-sorted sperm samples, a reduced DNA longevity in sex-sorted spermatozoa was detected when the samples were incubated for $48 \mathrm{~h}$ (65). Using the Sperm Chromatin Structure Assay (SCSA) assay, it was shown that sex-sorted spermatozoa had less homogenous sperm chromatin than controls (66). Flow cytometric sexing has also been shown to induce high levels of ROS in sperm samples. In stallion spermatozoa, the DNA fragmentation index post-sorting were $\sim 10 \%$ higher than pre-sorting, which may be due to oxidative DNA damage (67). Factors such as high pressure and speed, during sorting, dye-induced defects, electrical deviation, 
changes in $\mathrm{pH}$ and osmolarity, etc might lead to changes to the sperm plasma membrane, trigger pre capacitation-like changes, cause protamine decondensation and alter sperm DNA quality (68).

\section{Method and Season of Semen Collection}

The method of semen collection has an effect on sperm DNA quality; in farm animals, it was shown that use of an artificial vagina method was superior, in terms of sperm DNA integrity, to electroejaculation for semen collection. Similarly, seasonal variations, semen dilution and washing protocols to harvest good quality sperm cells also had a detrimental effect on the integrity of sperm DNA $(69,70)$. Further, comparatively lower DFI\% was observed in semen ejaculates collected during the breeding season as compared to the ejaculates obtained during the non-breeding season in bucks.

\section{Infection of Male Reproductive Organs}

Acute or chronic inflammation of male accessory sex glands is associated with a significant increase in ROS causing a marked reduction in semen quality and apoptosis of sperm cells (71). In human beings, it was shown that bacterial infections had significant negative effects on sperm chromatin condensation and protamine $\mathrm{P} 1 / \mathrm{P} 2$ ratio (72). In bulls, sperm DNA fragmentation increased because of bacterial growth during incubation of frozen-thawed semen. However, the increase in sperm DNA fragmentation was characteristic of some bulls but was not observed for others (73), indicating individual variations in susceptibility.

\section{WHY TEST SPERM DNA DAMAGE-CONSEQUENCES OF SPERM DNA FRAGMENTATION ON FERTILITY}

Sperm DNA is the only male heritable material present at the time of fertilization; therefore, transfer of sperm with damaged DNA can result in deleterious effects on the conceptus and impact on the successful development of an offspring too (74). The schematic representation of the causes and consequences of sperm DNA damage is given in Figure 1. The presence of sperm DNA as highly condensed chromatin renders it transcriptionally and translationally silent besides protecting the DNA from damage (75). Despite its highly complex structure, sperm DNA is susceptible to damage and nearly $80 \%$ of infertility cases due to idiopathic reasons are related to DNA integrity (11). The proportion of spermatozoa with DNA fragmentation was $34.5 \%$ in infertile men while it was only $14.9 \%$ in fertile men (76). Assessment of sperm DNA fragmentation represents a promising tool for clinical and research practice (77), although larger prospective trials are needed. Hitherto, it was believed that due to the high compaction of chromatin material in spermatozoa there is limited scope for DNA repair.

The DNA fragmentation index (DFI) is defined as the percentage of spermatozoa with either abnormal protamination or with DNA damage (78). Alterations in chromatin packaging/DNA integrity can occur at any stage, starting from the germ cell during spermatogenesis to ejaculated spermatozoa (28). Surprisingly, the oocyte retains the capacity to repair such damage, depending on type and degree, suggesting that spermatozoa with abnormal DNA retain the capacity to fertilize an oocyte. However, in most cases, such repair is

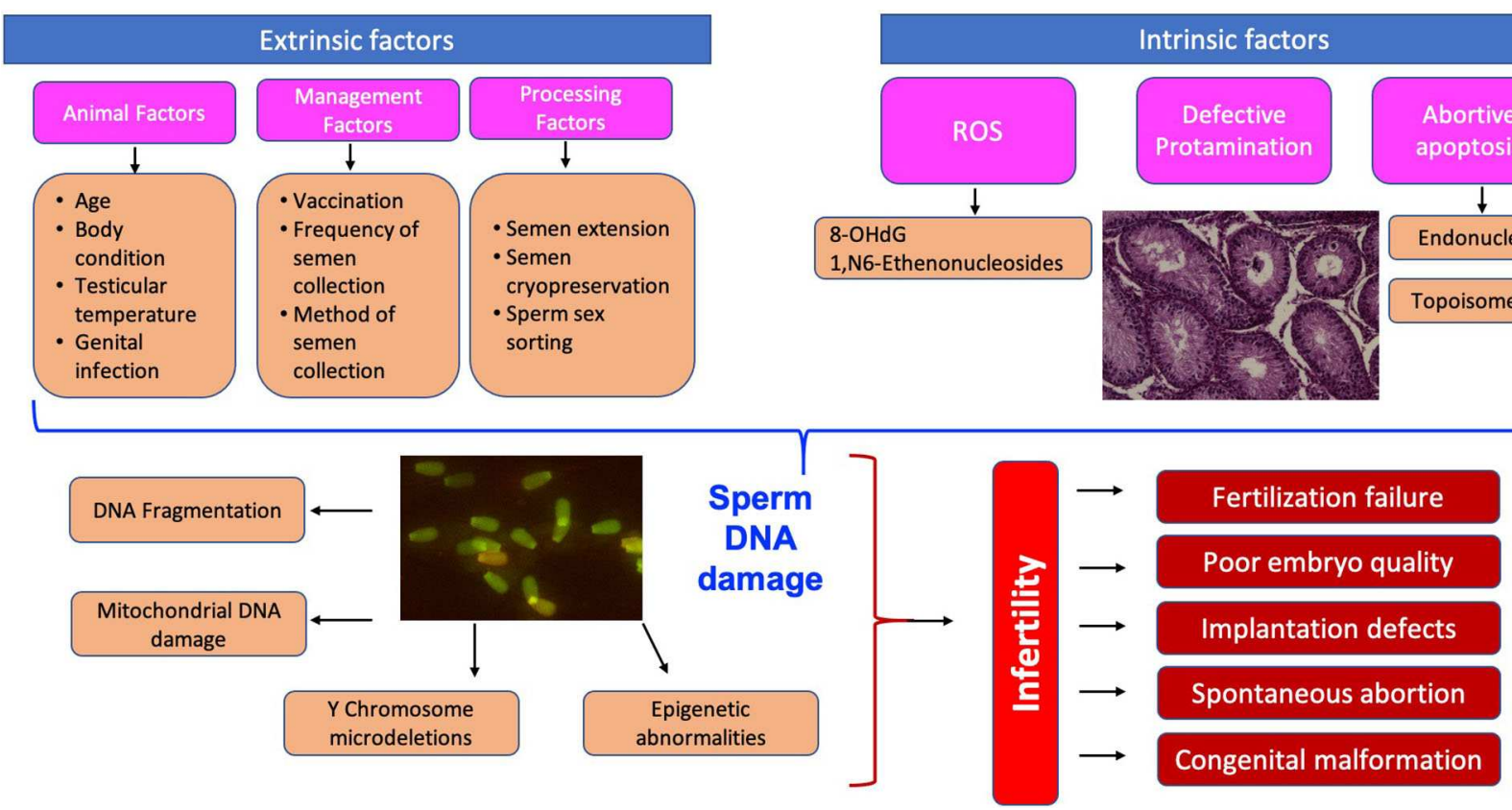

FIGURE 1 | Schematic representation of the causes and consequences of sperm DNA damage. 
followed by early embryonic mortality, implantation defect, chromosomal aberration and comparatively higher abortion rate (27). Furthermore, damaged DNA is negatively correlated to fertilization, implantation, pregnancy outcome and the well-being of the male reproductive tract $(79,80)$. Variations in DNA integrity and fertility level among individuals with a normal spermiogram are also quite high in mouse (81), men (82), bulls (83), stallions (19), and boars (17). In bulls, it was reported that the proportion of morphological normal spermatozoa was negatively correlated to DFI. Sperm DNA integrity in bulls show associations with morphological parameters, particularly with head shape abnormalities and indicators of spermatogenic immaturity, including proximal droplets (14). Fortes et al. (84) reported that sperm protamine content and sperm DNA damage are closely associated. In contrast, Castro et al. (83) indicated that protamine deficiency in bovine spermatozoa may not have a strong biological impact in explaining difference of in vitro fertility between bulls. Kipper et al. (85), evaluated sperm chromatin packing in relation to in vitro fertilization success rate in Nellore bulls and found that the proportion of spermatozoa with abnormal chromatin compaction did not interfere with early embryonic development. In boars, sperm DFI had a significant negative correlation with farrowing rate and the average number of pigs born per litter (86). However, more detailed information is required to better understand the relationship between DFI and boar fertility.

Eventually, with the increase in male infertility and pregnancy failure, Evenson et al. (24) used sperm chromatin structure assay (SCSA) for detection of qualitative DNA damage as an indicator of male fertility. In human beings, a DNA fragmentation index (DFI) $\geq 20 \%$ is associated with low fertility. Inseminating spermatozoa with compromised DNA, or performing assisted reproductive techniques (ART) without knowing the DNA status, can have a deleterious effect on fertility (9). Since then, a plethora of studies $(11,28,87)$ indicated the existence of a substantial correlation between DNA damage and idiopathic (in)fertility. These studies concluded that spermatozoa in the neat ejaculate with sperm DNA fragmentation (SDF) values below $15 \%$ should be regarded as normal for this parameter, those ranging from $>15 \%$ to $<30 \%$ are likely to have some fertility problems, whereas individuals with levels of SDF $>30 \%$ are considered to have substantial problems in producing offspring through natural conception (37). Sperm DNA assays could be one of the promising tools in selecting bulls for high fertility, since preliminary reports on sperm DFI and bull fertility indicate a significant relationship between these two parameters (13). Very recently, it was shown that measurement of DFI provides a simple, informative and reliable measure of sperm quality and can accurately predict male mouse fertility (81). These researchers observed that sperm DFI was significantly higher from males with low sperm counts compared to males with normal sperm counts, and viable embryos derived using spermatozoa from males with high DFI failed to produce offspring after embryo transfer compared to embryos from males with low DFI. Accumulated data show that DNA damage in mammalian species has biological consequences that vary according to the type of damage, location, cell or tissue involved. Such damage may induce temporary or permanent changes, either long-term or short-term. To improve the conception rate in artificial breeding and to reduce infertility in farm animals, it is essential to understand sperm DNA at the molecular level and the impact of sperm DNA integrity on field fertility.

\section{SPERM CHROMATIN STRUCTURE DURING AND AFTER SPERMATOGENESIS}

Spermatogenesis is a complex process involving several mitotic and meiotic divisions, followed by differentiation to produce fully mature haploid and polarized spermatozoa from a diploid spermatogonial stem cell. Spermatogenesis involves two steps, viz. spermatocytogenesis and spermiogenesis. Spermatocytogenesis is the process in which spermatogonia undergo proliferation, reduction division and differentiation to produce primary spermatocytes, secondary spermatocytes and finally spermatids. Subsequently, spermiogenesis involves a series of morphological transformations of immature spermatid to a mature spermatozoon. During the latter part of spermatogenesis, the chromatin material undergoes dramatic compaction, which renders spermatozoa transcriptionally silent, and cytoplasm is shed in the form of residual bodies (88). Meanwhile, the histoneDNA complexes of round spermatids are replaced by transition protein and then finally by protamine in elongated spermatids. Only $5-15 \%$ of histones are retained in DNA in spermatozoa from fertile men, whereas a comparatively higher proportion is retained in spermatozoa from infertile men (89). Nevertheless, these alterations instigate final condensation and stabilization of chromatin material, precisely portrayed in the mature phase of sperm cells. Sperm chromatin typically appears in a coiled fashion, called toroids, via formation of disulfide bonds (90) to protect DNA prior to fertilization. Around $50 \mathrm{~kb}$ of DNA is packaged into coiled toroids, attached to the nuclear matrix region by toroid linkers. Linker regions and histone-bound DNA are highly susceptible to DNA damage induced by endonucleases (91). Several researchers have demonstrated the negative effect of abnormal protamination in semen quality on the success of in vitro fertilization (IVF) and pregnancy rates in human patients $(43,92)$ and semen quality and fertility in bulls $(93,94)$. Furthermore, studies of Arpanahi et al. (95) and Hammound et al. (96) highlighted the significant role of retained histones in early embryonic development, zygotic genome activation, signaling pathways and imprinting genes, in the case of human and rat spermatozoa. In addition, it is documented that loss of chromatin integrity is associated with sperm morphological abnormalities (97), loss of viability and progressive motility (98), reduced concentration (45) and sperm maturity (99). Furthermore, Carrel and Liu (100) and Virro et al. (99) depicted a strong association between loss of chromatin integrity and poor implantation or spontaneous abortion. Therefore, the highly specialized sperm cell acts not only as a genetic carrier to the oocyte but also undergoes changes during spermatogenesis that will later support the developing embryo and maintenance of pregnancy. 


\section{EPIGENETIC MODIFICATIONS AND MALE FERTILITY}

In the science of genetics, epigenetics is the study of changes in gene expression which occur without alterations in the DNA sequence. Basically, epigenetic changes involve interactions between DNA and protein, either short-term or inherited over a generation at various developmental stages of life. Spermatozoa have unique epigenetic modifications pertaining to DNA methylation, covalent histone modification, and chromatin remodeling (101). Such changes may be associated with either expression or silencing of genes endowed with beneficial or detrimental effects in an organism. Of all these epigenetic modifications, abnormal DNA methylation has emerged as one of the promising indicators of male infertility (102).

\section{DNA Methylation}

During condensation of nuclear material in elongated spermatids, DNA methylation occurs in the cytosine residues of CpG islands under the influence of DNA methyl transferase enzyme. Methylation regulates genes expression either by adding (hypermethylation), or removing methyl groups from the promoter region (hypomethylation). Hypermethylation is attributed to the shutdown of gene expression or transcriptional silencing whereby the formation of protein comes to a halt and the developing zygote utilizes stored maternal mRNAs until the activation of the zygotic gene (103). Besides, several processes such as genomic imprinting (104), inactivation of the X chromosome (105), DNA compaction (106), and gene silencing are critically involved in DNA methylation of germ cells. However, during development and maturation of germ cells, extensive removal of DNA methylation in the primordial germ cell transpires (107). Prior to meiosis, compaction of chromatin in the sperm cell renders it much denser than in somatic cells (106). Any exposure to a deleterious environment may change DNA methylation patterns in male germ cells and interfere with differentiation into functional sperm cells, ultimately impairing male fertility. Any deviation in the methylation pattern limits the chances of successful fertilization and embryonic sustainability (108). A plethora of studies [e.g., $(96,109,110)]$ have also confirmed a positive correlation between abnormal methylation and male infertility, having a considerable influence on various seminal traits and pregnancy outcome. Several studies indicate the relationship of methylation status of genes with fertility (Table 1). Jena et al. (111) reported the effect of abnormal methylation pattern on the expression of IGF2 and H19 genes, which result in disruption of spermatogenesis, apart from producing spermatozoa with altered epigenetic marks, poor sperm quality and compromised fertility in crossbred bulls. Recently, Kropp et al. (118) also reported that bull fertility status is associated with DNA methylation signatures in spermatozoa. These researchers observed that preimplantation embryos derived from high and low fertility bulls displayed significant transcriptomic differences and there were differences in methylated regions which could influence the reprogramming of the early embryo. Tunc and Tremellen (119) also detailed the significant variation in spermatogenic efficiency and quality
TABLE 1 | Methylation status of selected genes in relation to fertility.

\begin{tabular}{|c|c|c|c|}
\hline Genes & Aberration & Male infertility & References \\
\hline H19, IGF2 & Hypomethylation & $\begin{array}{l}\text { Oligozoospermia and } \\
\text { infertility in crossbred } \\
\text { bulls }\end{array}$ & $(109,111)$ \\
\hline MTHFR & Hypermethylation & $\begin{array}{l}\text { Poor semen quality } \\
\text { and infertility }\end{array}$ & $(112,113)$ \\
\hline $\begin{array}{l}\text { PAX8, NTF3, SFN, } \\
\text { HRAS }\end{array}$ & Hypermethylation & $\begin{array}{l}\text { Oligozoospermia, } \\
\text { teratozoospermia } \\
\text { and } \\
\text { asthenozoospermia }\end{array}$ & $(114,115)$ \\
\hline RASGRF1 & $\begin{array}{l}\text { Hypermethylation at } \\
\text { an imprinted locus }\end{array}$ & $\begin{array}{l}\text { Poor semen } \\
\text { parameters in boar, } \\
\text { human and mice }\end{array}$ & $(93,116)$ \\
\hline GTL2 & $\begin{array}{l}\text { Hypermethylation at } \\
\text { an imprinted locus }\end{array}$ & $\begin{array}{l}\text { Poor semen } \\
\text { parameters }\end{array}$ & $(115,117)$ \\
\hline $\begin{array}{l}\text { PLAG1, D1RAS3, } \\
\text { MEST }\end{array}$ & $\begin{array}{l}\text { Hypermethylation at } \\
\text { imprinted locus }\end{array}$ & $\begin{array}{l}\text { Poor semen } \\
\text { parameters in human } \\
\text { and boar }\end{array}$ & $(109,115)$ \\
\hline $\begin{array}{l}\text { KCNQ1, LIT1, } \\
\text { SNRPN }\end{array}$ & $\begin{array}{l}\text { Hypermethylation at } \\
\text { imprinted locus }\end{array}$ & $\begin{array}{l}\text { Poor semen } \\
\text { parameters in human } \\
\text { and boar }\end{array}$ & $(96,115)$ \\
\hline
\end{tabular}

of semen among fertile and infertile groups of individuals in relation to global DNA methylation. Furthermore, infertile individuals with aberrant DNA methylation-imprinting were reported to have marked oligoasthenoteratozoospermia and oligozoospermia (120).

Techniques such as sex-sorting, vitrification and cryopreservation are reported to induce various degrees of DNA damage in bull spermatozoa (121). These processes result in abnormal methylation imprints which directly or indirectly reflect chromatin packaging (122) and, in turn, influence early embryonic developmental stages along with spermatogenesis of an embryo (123). When the status of DNA methylation was studied in boar sperm cells with different levels of DNA fragmentation, the number of differentially methylated cytosines was increased in the low-high compared to the lowmedium and the medium-high DFI groups (19). These latter researchers concluded that with increasing DNA fragmentation in spermatozoa, there is an increase in the number of potentially affected downstream genes and their respective regulatory pathways. Although several researchers $(109,124,125)$ have documented sperm and testicular methylation profiles in groups of fertile and infertile individual pertaining to promoter region, genes and imprinted regions, the mechanism elucidating such alteration and contributing to compromised fertility is still a matter of debate.

\section{Sperm Histone Modification}

In mature spermatozoa, depending upon the species, between 2 and $15 \%$ of sperm chromatin is bound to histones, rather than to protamines (126). Although the ratio of nucleohistone to nucleoprotamine ratio is very low, it still plays a significant role in gametogenesis. Generally, histones are octameric and have four types of histone proteins in the core of the nucleosomes: 
$\mathrm{H} 2 \mathrm{~A}, \mathrm{H} 2 \mathrm{~B}, \mathrm{H} 3$, and $\mathrm{H} 4$. On the other hand, arginine- and lysineenriched histone tails remain on the surface of the nucleosomes. Basically, all these histone proteins are susceptible to covalent modifications such as acetylation, methylation, phosphorylation, and ubiquitination. Most of these modifications occur under the influence of specific enzymes limited to the tail regions only, but modifications of histones in the core region are still under debate. However, recent research has elucidated the role of core histone modifications in the transcription process, as well as in the DNA repair mechanism, and replication and adjustment of cells. In addition, all the above post-translational modifications alter the DNA binding pattern, along with the interaction of other regulatory factors, and change the expression of genes (127). In other words, post-translational modification of histones is regulated by a number of molecules, which in turn modulate the chromatin architecture and may be involved in an alteration in fertility (Table 2). Gene activation or repression, instigated by methylation of histones, occurs under the influence of HMTase on H3 or H4. Moreover, Okada et al. (130) reported that methylation is an integral part of spermatogenesis. The progression of spermatogenesis is determined by the number of methyl groups added to $\mathrm{H} 3 \mathrm{~K} 4, \mathrm{H} 3 \mathrm{~K}$, or H3K27 (141), where methylation of H3K4 correlates with the functional competence of the spermatogonial stem cell to develop into fully mature spermatozoa, whereas methylation of $\mathrm{H} 3 \mathrm{~K} 9$ or $\mathrm{H} 3 \mathrm{k} 27$ highlights gene silencing in the germ cell, eventually occurring after the commencement of meiosis. In light of this fact, any disruption to $\mathrm{H} 3 \mathrm{~K}$, demethylase JHDM2A (JmjC domain-containing histone demethylase 2A) and curtailment of the expression of protamine 1 and transition protein and decondensation of chromatin, subsequently result in infertility (130). Similarly, histone acetylation in elongating spermatids also plays a crucial role in the condensation of chromatin materials by replacing histone and transition protein by protamine; low hyperacetylation is reported in infertile men with aberrant spermatogenesis (142). Moreover, acetylation is controlled by two types of enzymes viz. acetyltransferases and deacetyltransferases, where acetyltransferases activate gene expression and deacetyl transferases inhibit gene expression (143). Besides, phosphorylation on serine residues leads to gene activation while phosphorylation on the histone variant causes chromatin condensation and gene silencing. On the other hand, during postmeiotic stages of spermatogenesis, RNF8dependant ubiquitinylation of histones $\mathrm{H} 2 \mathrm{~A}$ and $\mathrm{H} 2 \mathrm{~B}$ favors the exchange of histone protein to transition protein (144). Furthermore, deficiency of RNF8 is reported to cause failure in chromatin condensation, loss in sperm motility, reduction in sperm concentration in the epididymis, increased retention of the residual body and reduced capacity to fertilize oocytes (144). In addition, small ubiquitin-like modifiers (SUMOs) also take part in epigenetic modification by regulating gene expression (140).

\section{Chromatin Remodeling}

Unlike the above two processes of epigenetic modification, chromatin remodeling occurs by shifting of histone proteins along the DNA and consequently results in alteration of sperm physiology. Generally, one phosphate group from an ATP
TABLE 2 | Selected molecules involved in post -translational histone modification in relation to fertility.

\begin{tabular}{|c|c|c|}
\hline Genes & Function & References \\
\hline $\begin{array}{l}\text { Suv39h1 (Histone-Lysine } \\
\text { N-Methyltransferase, H3 Lysine-9 } \\
\text { Specific 1) }\end{array}$ & $\begin{array}{l}\text { Histone methylation } \\
(\mathrm{H} 3)\end{array}$ & $(128,129)$ \\
\hline $\begin{array}{l}\text { LSD1 (Lysine (K) -Specific } \\
\text { Demethylase 1) }\end{array}$ & $\begin{array}{l}\text { Histone demethylation } \\
(\mathrm{H} 3)\end{array}$ & $(130)$ \\
\hline HATs (Histone Acetyltransferase 1) & Histone acetylation (H4) & $(131)$ \\
\hline $\begin{array}{l}\text { MYST (MYST Iysine } \\
\text { acetyltransferases) }\end{array}$ & Histone acetylation $(\mathrm{H} 4)$ & $(132)$ \\
\hline HDACs (Histone Deacetylase 1) & $\begin{array}{l}\text { Histone deacetylation } \\
(\mathrm{H} 4)\end{array}$ & $(131)$ \\
\hline SIRT1 (sirtuin family) & $\begin{array}{l}\text { Histone deacetylation } \\
(\mathrm{H} 1, \mathrm{H} 3, \mathrm{H} 4)\end{array}$ & $(133)$ \\
\hline MUTp & $\begin{array}{l}\text { Histone } \\
\text { phosphorylation }(\mathrm{H} 2 \text {, } \\
\mathrm{H} 3)\end{array}$ & $(134)$ \\
\hline NHK-1 & $\begin{array}{l}\text { Histone } \\
\text { phosphorylation (H2) }\end{array}$ & $(135)$ \\
\hline G9a & $\begin{array}{l}\text { Histone methylation } \\
(\mathrm{H} 3)\end{array}$ & $(136)$ \\
\hline MSK1, MSK2 & $\begin{array}{l}\text { Histone } \\
\text { phosphorylation (H3) }\end{array}$ & $(137)$ \\
\hline PKA & $\begin{array}{l}\text { Histone } \\
\text { phosphorylation (H3) }\end{array}$ & $(138)$ \\
\hline HR6B & $\begin{array}{l}\text { Histone ubiquitylation } \\
(\mathrm{H} 2)\end{array}$ & $(139)$ \\
\hline $\begin{array}{l}\text { E1 SUMO-activating enzyme 1, E1 } \\
\text { SUMO-activating enzyme 2, UBC9 }\end{array}$ & $\begin{array}{l}\text { Histone sumoylation } \\
(\mathrm{H} 4)\end{array}$ & $(140)$ \\
\hline
\end{tabular}

molecule is utilized to loosen the tight packaging of chromatin, thereby allowing DNA-binding factors or other transcription factors to access the unwound DNA and regulate gene expression based on exposure of sequences (145). Furthermore, an additional function of chromatin remodeling is DNA replication and repair of DNA damage. Basically, two ubiquitous families, such as SWI/SNF and the ISWI family are involved in this process.

\section{METHODS FOR ASSESSMENT OF SPERM DNA DAMAGE}

During the past few decades, a variety of assays has emerged to detect sperm DNA damage and some new tests are under investigation. Briefly, the principle of these techniques is based on incorporation of chromatin probes, mild acid denaturation to the fragmented DNA, staining for the evaluation of sperm DNA damage and oxidation-reduction potential (ORP). Double or single DNA strand breaks are estimated either directly or indirectly. Direct tests comprise the comet assay (single cell gel electrophoresis) forming comet tail and cell head in alkaline or neutral $\mathrm{pH}$ conditions, which can be visualized using epifluorescence microscopy after staining. The comet tail length and fluorescence intensity in the cell head determine the degree of DNA fragmentation (146), whereas terminal 
deoxynucleotidyl transferase dUTP nick-end labeling (TUNEL) assay (147) determines only the fluorescently labeled nucleotides. Apart from these assays, in situ nick translation (ISNT) (148) and DNA breakage detection fluorescence in situ hybridization (DBD-FISH) (149) and ORP (150) are some of the emerging assays for sperm DNA fragmentation. Indirect tests include DNA denaturability, such as the sperm chromatin structure assay (SCSA) $(24,151)$, Acridine orange (AO), sperm chromatin dispersion (SCD) test (152), and toluidine blue assay (153). These tests make use of DNA intercalating dyes to emit green to red fluorescence based on the attachment to double/single strand fragmented DNA, whereas staining the lysine residue of histones with CMA3 flurochrome competes for the protamine binding site and thus efficiently detects sperm chromatin integrity and packaging. Since protamine deficiency is likely to be one of the contributing factors to DNA instability and damage, which can affect bull fertility, Fortes et al. (84) assessed protamine deficiency in bull spermatozoa using the sperm protamine deficiency assay (SPDA) and concluded that sperm protamine content and sperm DNA damage are closely associated. Very recently, MiOXSYS System has come in to existence as a novel technology to detect ORP in human semen samples, because ORP has a positive correlation between the proportion of abnormal sperm heads and sperm DNA fragmentation $(154,155)$. On the other hand, estimation of DNA adducts, 8-OHDG level by liquid chromatography (156) and Raman spectroscopy to fingerprint the chemical composition of semen sample (157), can also be used to predict \%DFI. Furthermore, assessment of global DNA methylation level has recently become possible, but the correlation with sperm parameters is yet to be defined (158). The ability of these techniques to estimate sperm DNA damage accurately depends on many technical and biological aspects. The principles, advantages and limitations of a few commonly used tests for sperm DNA damage are summarized in Table 3.

Several studies compared different assays for assessment of sperm DNA fragmentation. However, in spite of intensive research, no consensus has yet been reached as to which tests are most predictive of fertility. In men, the alkaline COMET assay was reported to be the best in predicting male infertility, followed by TUNEL, SCD, and SCSA, whereas the neutral COMET assay had no predictive power (169). Martínez-Pastor et al. (170) compared SCSA and SCD for assessing the chromatin status in bulls and reported that SCD had lower repeatability compared to SCSA. In stallions, Serafini et al. (171) observed that both the neutral comet assay and the SCSA could successfully identify sperm DNA quality. Several studies suggested that the SCSA assay may be an important assay for identification of men $(9,172,173)$, bull $(14,94,174,175)$, boar $(86,176)$, and ram (177) with potentially lowered fertility. Using the SCSA assay, the threshold values for farm animals have been established. The estimated threshold above which the SCSA \%DFI has a detrimental impact on fertility varies across species e.g., pigs, 6\%; bulls 10-20\%; horses: 28\%; men 25-30\% (178). In the same context, Kumaresan et al. (13) developed a bull fertility prediction model based on PCA analysis of \%DFI and some other seminal attributes, which discriminated above average bulls from below average fertility bulls with a fair degree of $\operatorname{accuracy}\left(R^{2}=0.83\right)$.

\section{PROGNOSTIC VALUE OF SPERM DNA QUALITY}

With the breakthrough in sperm chromatin quality assessment techniques, the prognostic value of sperm DNA quality has improved, in contrast to routine semen analysis $(37,178)$. Several studies traced the clinical significance of various DNA fragmentation assays in semen quality and fertility in men $(89,179-181)$, bull $(13,174,182)$, boar $(86,176)$, and stallion (183). Normally, reductions in fertilization rate, embryo quality, implantation rate, chromosomal aberration, and repeated abortions are associated with sperm DNA fragmentation. Several studies indicated the usefulness of sperm DNA integrity as a tool for fertility assessment $(13,81,178,182)$. In contrast, \%DFI was reported to have a low impact on fertilization (184), implantation rates (185), and embryo quality (186). In the case of bulls, Castro et al. (83) reported that protamine deficiency in bovine spermatozoa may not have a strong biological significance to explain the fertility difference among individual bulls. Therefore, as of now, the prognostic value of DNA fragmentation remains controversial, as it is coupled with many other factors, such as semen collection and processing procedures, insemination technique and method of assessment of DNA fragmentation (TUNEL, SCSA, SCD, AO, and COMET assay). Besides, several researchers showed seminal parameters to be within normal ranges (such as motility, concentration and morphology) with varying degrees of sperm DNA fragmentation assessed using SCSA \&TUNEL assays, but reported compromised fertilization $(80,151,187)$. Values of $\%$ DFI above $30 \%$ in infertile men, $28 \%$ in the stallion and $10-20 \%$ in bulls, were reported to be associated with a failure to maintain pregnancy although the sperm were able to fertilize oocytes. Karoui et al. (174) also related \%DFI values of 7 to $10 \%$ with a poor success rate of Artificial Insemination (AI) in bulls. Although several studies on sperm DFI in men are available $(9,11,89)$, discriminating between fertile and sub-fertile individuals, few reports are available on farm animals. In a study evaluating sperm DNA damage in bulls and men of known fertility, it was found that infertile bull sperm showed 1.6-fold higher DNA fragmentation rates compared to bulls of proven fertility, and sperm from infertile men showed a 2.25-fold increase in sperm DNA fragmentation compared to fertile men (24). In a recent study, \%DFI was negatively and significantly correlated to bull fertility; spermatozoa from below average fertility bulls showed 2.16-fold higher \%DFI as compared to above-average fertility bulls (12). After analyzing the trends in sperm DNA fragmentation assessment over a period of 20 years, Baskaran et al. (188) concluded that sperm DNA fragmentation was predominantly investigated in relation to lifestyle and a few infertile conditions, and a substantial increase in research is warranted to establish sperm DNA fragmentation as a prognostic/diagnostic parameter to evaluate clinical scenarios and ART outcomes in human beings. 
TABLE 3 | Different methods for detection of DNA damage in spermatozoa.

\begin{tabular}{|c|c|c|c|c|c|}
\hline Assay & Method & Principle & Advantages & Limitations & References \\
\hline $\begin{array}{l}\text { Sperm chromatin } \\
\text { structure assay }\end{array}$ & Flowcytometry & $\begin{array}{l}\text { Measure the DNA denaturation } \\
\text { (acid/heat) based on the } \\
\text { metachromatic shift from green to } \\
\text { red fluorescence }\end{array}$ & $\begin{array}{l}\text { The SCSA accurately estimates } \\
\text { the percentage of DNA-damaged } \\
\text { sperm }\end{array}$ & $\begin{array}{l}\text { Requires expensive } \\
\text { instrumentation (flow cytometer) } \\
\text { and HIGHLY } \\
\text { orthochromatic staining Skilled } \\
\text { technicians }\end{array}$ & $(24)$ \\
\hline $\begin{array}{l}\text { Sperm chromatin } \\
\text { dispersion test }\end{array}$ & $\begin{array}{l}\text { Fluorescence } \\
\text { Microscopy }\end{array}$ & $\begin{array}{l}\text { Differentiate between fragmented } \\
\text { and non-fragmented DNA based } \\
\text { on the presence of peripheral halo } \\
\text { dispersion in DNA loops. }\end{array}$ & $\begin{array}{l}\text { Simple, fast, and reproducible, } \\
\text { and results are comparable to } \\
\text { those of the SCSA. Does not } \\
\text { require expensive instrumentation. }\end{array}$ & $\begin{array}{l}\text { Recently introduced test, thus } \\
\text { little is known about its limitations } \\
\text { and its clinical significance }\end{array}$ & $(159)$ \\
\hline Toluidine & Microscopy & $\begin{array}{l}\text { Used for metachromatic and } \\
\text { orthochromatic staining of } \\
\text { chromatin. This stain is a sensitive } \\
\text { structural probe for DNA structure } \\
\text { and packaging. }\end{array}$ & $\begin{array}{l}\text { Simple and inexpensive and have } \\
\text { the advantage of providing } \\
\text { permanent } \\
\text { preparations for use on an } \\
\text { ordinary microscope }\end{array}$ & $\begin{array}{l}\text { Inherent limitation of repeatability } \\
\text { dictated by dye equilibrium } \\
\text { variations and only limited } \\
\text { number of cells can be } \\
\text { reasonably scored }\end{array}$ & $(160)$ \\
\hline Chromomycin A3 & $\begin{array}{l}\text { Fluorescent } \\
\text { Microscopy/Flow } \\
\text { cytometry }\end{array}$ & $\begin{array}{l}\text { Chromomycin } \mathrm{A}_{3} \text { and protamines } \\
\text { compete for the same binding } \\
\text { sites in the DNA. High CMA3 } \\
\text { fluorescence indicates low } \\
\text { protamination state of } \\
\text { spermatozoa }\end{array}$ & $\begin{array}{l}\text { The CMA3 assay yields reliable } \\
\text { results as it is strongly correlated } \\
\text { with other assays used in the } \\
\text { evaluation of sperm chromatin }\end{array}$ & $\begin{array}{l}\text { Observer subjectivity may hinder } \\
\text { the results if fluorescent } \\
\text { microscopy is used. } \\
\text { Expensive instrumentation, if } \\
\text { flow cytometry is used }\end{array}$ & $(161)$ \\
\hline Acridine orange & $\begin{array}{l}\text { Fluorescent } \\
\text { Microscopy/ } \\
\text { flowcytometry }\end{array}$ & $\begin{array}{l}\text { Measures the susceptibility of } \\
\text { sperm nuclear DNA to } \\
\text { acid-induced denaturation in situ } \\
\text { by quantifying the metachromatic } \\
\text { shift of AO fluorescence from } \\
\text { green (native DNA) to red } \\
\text { (denatured DNA) }\end{array}$ & $\begin{array}{l}\text { The } \mathrm{AO} \text { assay is a biologically } \\
\text { stable measure of sperm quality. } \\
\text { The inter-assay variability is }>5 \% \text {, } \\
\text { rendering the technique highly } \\
\text { reproducible }\end{array}$ & $\begin{array}{l}\text { Observer subjectivity may hinder } \\
\text { the results if fluorescent } \\
\text { microscopy is used expensive } \\
\text { instrumentation, if flow cytometry } \\
\text { is used }\end{array}$ & $(162-164)$ \\
\hline Aniline & Microscopy & $\begin{array}{l}\text { Discriminates between lysine-rich } \\
\text { histone and cysteine/arginine-rich } \\
\text { protamine }\end{array}$ & $\begin{array}{l}\text { Simple and inexpensive and have } \\
\text { the advantage of providing } \\
\text { permanent } \\
\text { preparations for use on an } \\
\text { ordinary microscope }\end{array}$ & $\begin{array}{l}\text { Inherent limitation of repeatability } \\
\text { dictated by dye equilibrium } \\
\text { variations and only limited } \\
\text { number of cells can be } \\
\text { reasonably scored }\end{array}$ & $(160)$ \\
\hline TUNEL & $\begin{array}{l}\text { Flowcytometry/ } \\
\text { Fluorescence } \\
\text { Microscopy }\end{array}$ & $\begin{array}{l}\text { The TUNEL assay quantifies the } \\
\text { incorporation of dUTP at single- } \\
\text { and double-strand DNA breaks }\end{array}$ & $\begin{array}{l}\text { The assay demonstrated } \\
\text { fairly good quality control } \\
\text { parameters. The intra-observer } \\
\text { variability was found to be }<8 \% \\
\text { and the } \\
\text { interobserver variability was }<7 \%\end{array}$ & $\begin{array}{l}\text { Expensive instrumentation, if } \\
\text { flow cytometry is used }\end{array}$ & $(165)$ \\
\hline Comet & $\begin{array}{l}\text { Fluorescent } \\
\text { Microscopy }\end{array}$ & $\begin{array}{l}\text { Quantifies the actual DNA } \\
\text { damage in both alkaline and } \\
\text { neutral method based on tail } \\
\text { length. }\end{array}$ & $\begin{array}{l}\text { The comet is a simple and } \\
\text { well-standardized low-cost assay } \\
\text { that correlates significantly with } \\
\text { TUNEL and SCSA assays }\end{array}$ & $\begin{array}{l}\text { The assay requires an } \\
\text { experienced observer to analyze } \\
\text { the slides and interpret the } \\
\text { results }\end{array}$ & $(166,167)$ \\
\hline $\begin{array}{l}\text { In situ nick } \\
\text { translation (INST) }\end{array}$ & $\begin{array}{l}\text { Fluorescent } \\
\text { Microscopy }\end{array}$ & $\begin{array}{l}\text { Specifically stains spermatozoa } \\
\text { that contain appreciable and } \\
\text { variable levels of endogenous } \\
\text { DNA damage. }\end{array}$ & $\begin{array}{l}\text { The advantage of the NT assay is } \\
\text { that the reaction is based on } \\
\text { direct labeling of termini of DNA } \\
\text { breaks, and thus the lesions that } \\
\text { are measured are identifiable at } \\
\text { the molecular level }\end{array}$ & $\begin{array}{l}\text { Expensive instrumentation, if } \\
\text { flow cytometry is used }\end{array}$ & $(168)$ \\
\hline 8-OHDG & $\begin{array}{l}\text { Liquid } \\
\text { chromatography }\end{array}$ & $\begin{array}{l}\text { It is the most commonly studied } \\
\text { biomarker for oxidative DNA } \\
\text { damage. Estimates the level of } \\
\text { DNA adducts which generate } \\
\text { DNA strand breaks. }\end{array}$ & Specificity and sensitivity are high. & $\begin{array}{l}\text { Although } 8-O H d G \text { is a potential } \\
\text { marker for oxidative DNA } \\
\text { damage, artifactual oxidation of } \\
\text { dG can occur during the } \\
\text { analysis, which can lead to } \\
\text { inaccurate results }\end{array}$ & $(156)$ \\
\hline $\begin{array}{l}\text { Oxidation- } \\
\text { reduction potential } \\
(\mathrm{ORP})\end{array}$ & $\begin{array}{l}\text { MiOXSYS } \\
\text { System }\end{array}$ & $\begin{array}{l}\text { Direct measure of Oxidative } \\
\text { Stress in semen sample, as it } \\
\text { describes the relative proportions } \\
\text { of oxidants (ROS) to reductants } \\
\text { (antioxidants) }\end{array}$ & $\begin{array}{l}\text { Reproducibility of the results are } \\
\text { high }\end{array}$ & $\begin{array}{l}\text { Very recently introduced test, } \\
\text { thus little is known about its } \\
\text { limitations and its clinical } \\
\text { significance }\end{array}$ & $(154)$ \\
\hline
\end{tabular}




\section{BOTTOM LINE}

Traditional routine semen analysis has limited value for the prediction of sperm fertilizing potential. The prognostic value of the currently available in vitro tests for male fertility prediction is also limited. The data accumulated over the last four decades, mostly on men, indicate that DNA integrity correlates well with sperm fertility potential. Furthermore, the majority of the studies indicates that DNA damage assessment has a better predictive score than conventional semen analysis. In the era of assisted reproductive techniques (ART), evaluation of the quality of the sperm genome and selection of good quality spermatozoa assume much significance for desirable pregnancy outcome. The assessment of sperm DNA damage in ART, such as in vitro embryo production, is important because these techniques bypass the natural selection barriers of the female reproductive tract. When spermatozoa with a lot of DNA damage are used, the possibilities of transmitting genetic aberrations to the embryo/fetus are high. It has been demonstrated that assessment of the sperm DNA fragmentation index and selection of spermatozoa with low \%DFI prior to ART, improved fertilization rates. Several studies indicate that sperm DNA damage is negatively associated with male fertility, fertilization, and embryonic development. A recent report indicated that sperm \%DFI was significantly higher $(P<$ 0.01 ) in male factor infertility compared to either female factor or unknown factor infertility (12). Therefore, the inclusion of the DNA fragmentation index in breeding soundness evaluation could be a better prognostic value for selection of quality breeding males for an artificial breeding programme.

On the research front, we still have a long way to go to understand fully the impact of fertilization of an oocyte by a spermatozoon with damaged DNA. The majority of the earlier studies reported the relationship of sperm DNA damage with fertility but limited information is available on the molecular details of how damaged sperm DNA affects fertilization and postfertilization embryo/fetus development. In addition, the longterm consequences of using sperm with compromised DNA integrity are unknown. To make it possible to assess sperm DNA in frozen semen stations, a precise and simplified novel method is required. Whatever the assay to be developed or refined, it should allow assessment of sperm DNA integrity without destruction of the fertilizing potential of spermatozoa so that the same germ cell

\section{REFERENCES}

1. Mascarenhas MN, Flaxman SR, Boerma $\mathrm{T}$, Vanderpoel $\mathrm{S}$, Stevens GA. National, regional, and global trends in infertility prevalence since 1990: a systematic analysis of 277 health surveys. PLoS Med. (2012) 9:e1001356. doi: 10.1371/journal.pmed. 1001356

2. Dobson H, Walker SL, Morris MJ, Routly JE, Smith RF. Why is it getting more difficult to successfully artificially inseminate dairy cows?. Animal. (2008) 2:1104-11. doi: 10.1017/S175173110800236X

3. Hirsh A. Male subfertility. BMJ. (2003) 327:669-72. doi: 10.1136/ bmj.327.7416.669

4. Thippeswamy VB, Layek SS, Kumaresan A, Mohanty TK, Gupta AK, Chakravarty $\mathrm{AK}$, et al. Effects of pedigree and exotic genetic inheritance could be used for assessment and subsequently for fertilization; this would provide a safe and effective diagnostic method in cases opting for ART.

\section{CONCLUSION}

There is consensus among the researchers that DNA damage is greater in infertile males compared to fertile males in several species. The available literature also convincingly shows that sperm DNA damage influences the fertility outcome to a variable degree. Although several methods are used to assess sperm DNA damage, the different types of DNA defects and inconsistency in reproducibility of results, indicate that it may be necessary to use a combination of tests for reliable and reproducible results. However, it is noteworthy that the majority of the information generated was from men; largescale studies using appropriate samples/methodologies are very limited in farm animals. Although, a substantial increase in research is warranted to establish sperm DNA damage as a prognostic/diagnostic parameter to evaluate male fertility in farm animals, based on the information available, across the species, it may be inferred that incorporation of sperm DNA fragmentation assay in the breeding soundness evaluation could improve the accuracy of selection of quality breeding males for an artificial breeding programme.

\section{AUTHOR CONTRIBUTIONS}

AK and JM conceptualized the review. All of the authors were involved in literature review, development of the manuscript, and approved the manuscript for publication.

\section{FUNDING}

AK acknowledges the Indian Council of Agricultural Research (ICAR), New Delhi, India and National Dairy Research Institute, Karnal, India for permitting him to undergo research cum training program at the Department of Clinical Sciences/Division of Reproduction, Swedish University of Agricultural Sciences, Uppsala, Sweden. The training was a part of "Lal Bahadur Shastri Young Scientist Award" awarded by the ICAR to AK. Part of the work was financed by a grant from The Swedish Farmers' Foundation (Stockholm) to JM. 3:13-7. doi: 10.1016/S2305-0500(13)60178-5

5. Brandes M, Hamilton CJCM, van der Steen JOM, De Bruin JP, Bots RSGM, Nelen WLDM, et al. Unexplained infertility: overall ongoing pregnancy rate and mode of conception. Hum Reprod. (2010) 26:3608. doi: 10.1093/humrep/deq349

6. Esteves SC, Zini A, Aziz N, Alvarez JG, Sabanegh ES Jr, Agarwal A. Critical appraisal of World Health Organization's new reference values for human semen characteristics and effect on diagnosis and treatment of subfertile men. Urology. (2012) 79:16-22. doi: 10.1016/j.urology.2011. 08.003

7. O'Brien KLF, Varghese AC, Agarwal A. The genetic causes of male factor infertility: a review. Fertil Steril. (2010) 93:112. doi: $10.1016 /$ j.fertnstert.2009.10.045 
8. Schulte RT, Ohl DA, Sigman M, Smith GD. Sperm DNA damage in male infertility: etiologies, assays, and outcomes. J Assist Reprod Genet. (2010) 27:3-12. doi: 10.1007/s10815-009-9359-x

9. Evenson DP, Jost LK, Marshall D, Zinaman MJ, Clegg E, Purvis K, et al. Utility of the sperm chromatin structure assay as a diagnostic and prognostic tool in the human fertility clinic. Hum Reprod. (1999) 14:103949. doi: 10.1093/humrep/14.4.1039

10. Zini A. Are sperm chromatin and DNA defects relevant in the clinic?. Syst Biol Reprod Med. (2011) 57:78-85. doi: 10.3109/19396368.2010.515704

11. Lewis SE, Aitken RJ, Conner SJ, De Iuliis G, Evenson DP, Henkel R, et al. The impact of sperm DNA damage in assisted conception and beyond: recent advances in diagnosis and treatment. Reprod Biomed Online. (2013) 27:325-37. doi: 10.1016/j.rbmo.2013.06.014

12. Kumaresan A, Johannisson A, Nordqvist S, Kårehed K, Åkerud H, Lindgren KE, et al. Relationship of DNA integrity to HRG C633T SNP and ART outcome in infertile couples. Reproduction. (2017) 153:86576. doi: 10.1530/REP-17-0058

13. Kumaresan A, Johannisson A, Al-Essawe EM, Morrell JM. Sperm viability, reactive oxygen species, and DNA fragmentation index combined can discriminate between above-and below-average fertility bulls. J Dairy Sci. (2017) 100:5824-36. doi: 10.3168/jds.2016-12484

14. Boe-Hansen GB, Fortes MS, Satake N. Morphological defects, sperm DNA integrity, and protamination of bovine spermatozoa. Andrology. (2018) 6:627-33. doi: 10.1111/andr.12486

15. Baumber J, Ball BA, Linfor JJ, Meyers SA. Reactive oxygen species and cryopreservation promote DNA fragmentation in equine spermatozoa. $J$ Androl. (2003) 24:621-8. doi: 10.1002/j.1939-4640.2003.tb02714.x

16. Neuhauser $S$, Bollwein $H$, Siuda $M$, Handler J. Effects of different freezing protocols on motility, viability, mitochondrial membrane potential, intracellular calcium level, and dna integrity of cryopreserved equine epididymal sperm. J Equine Vet Sci. (2019) 82:102801. doi: 10.1016/j.jevs.2019.102801

17. Boe-Hansen GB, Ersbøll AK, Greve T, Christensen P. Increasing storage time of extended boar semen reduces sperm DNA integrity. Theriogenology. (2005) 63:2006-19. doi: 10.1016/j.theriogenology.2004.09.006

18. Peña ST Jr, Gummow B, Parker AJ, Paris DB. Antioxidant supplementation mitigates DNA damage in boar (Sus scrofa domesticus) spermatozoa induced by tropical summer. PLoS ONE. (2019) 14:e0216143. doi: 10.1371/journal.pone.0216143

19. Khezri A, Narud B, Stenseth EB, Johannisson A, Myromslien FD, Gaustad $\mathrm{AH}$, et al. DNA methylation patterns vary in boar sperm cells with different levels of DNA fragmentation. BMC Genomics. (2019) 20:897. doi: 10.1186/s12864-019-6307-8

20. Falchi L, Galleri G, Zedda MT, Pau S, Bogliolo L, Ariu F, et al. Liquid storage of ram semen for $96 \mathrm{~h}$ : Effects on kinematic parameters, membranes and DNA integrity, and ROS production. Livest Sci. (2018) 207:1-6. doi: 10.1016/j.livsci.2017.11.001

21. Peris-Frau P, Álvarez-Rodríguez M, Martín-Maestro A, Iniesta-Cuerda M, Sánchez-Ajofrín I, Garde JJ, et al. Comparative evaluation of DNA integrity using sperm chromatin structure assay and Sperm-Ovis-Halomax during in vitro capacitation of cryopreserved ram spermatozoa. Reprod Domestic Anim. (2019) 54:46-9. doi: 10.1111/rda.13519

22. Kadioglu A, Ortac M. The role of sperm DNA testing on male infertility. Transl Androl Urol. (2017) 6:600. doi: 10.21037/tau.2017.03.82

23. Alfert $M$. Chemical differentiation of nuclear proteins during spermatogenesis in the salmon. J Cell Biol. (1956) 2:10914. doi: $10.1083 /$ jcb.2.2.109

24. Evenson DP, Darzynkiewicz Z, Melamed MR. Relation of mammalian sperm chromatin heterogeneity to fertility. Science. (1980) 210:11313. doi: $10.1126 /$ science. 7444440

25. Shamsi MB, Venkatesh S, Tanwar M, Singh G, Mukherjee S, Malhotra N, et al. Comet assay: a prognostic tool for DNA integrity assessment in infertile men opting for assisted reproduction. Ind J Med Res. (2010) 131:675.

26. Francavilla S, D'Abrizio P, Cordeschi G, Pelliccione F, Necozione S, Ulisse $\mathrm{S}$, et al. Fas expression correlates with human germ cell degeneration in meiotic and post-meiotic arrest of spermatogenesis. MHR. (2002) 8:21320. doi: $10.1093 / \mathrm{molehr} / 8.3 .213$
27. Tesarik J, Greco E, Mendoza C. Late, but not early, paternal effect on human embryo development is related to sperm DNA fragmentation. Hum Reprod. (2004) 19:611-5. doi: 10.1093/humrep/deh127

28. González-Marín C, Gosálvez J, Roy R. Types, causes, detection and repair of DNA fragmentation in animal and human sperm cells. Int J Mol Sci. (2012) 13:14026-52. doi: 10.3390/ijms1311 14026

29. Kuchakulla M, Narasimman M, Khodamoradi K, Khosravizadeh Z, and Ramasamy R. How defective spermatogenesis affects sperm DNA integrity. Andrologia. (2020) e13615. doi: 10.1111/and.13615. [Epub ahead of print].

30. Windt ML, De Beer PM, Franken DR, Rhemrev J, Menkveld R, Lombard CJ, et al. Sperm decondensation and semen parameters: utilization of a simple staining technique for the evaluation of human sperm decondensation. Andrologia. (1994) 26:67-72. doi: 10.1111/j.1439-0272.1994.tb00759.x

31. Peña FJ, O’Flaherty C, Ortiz Rodríguez JM, Martín Cano FE, GaitskellPhillips GL, Gil MC, et al. Redox regulation and oxidative stress: the particular case of the stallion spermatozoa. Antioxidants. (2019) 8:567. doi: $10.3390 /$ antiox 8110567

32. Agarwal A, Saleh RA, Bedaiwy MA. Role of reactive oxygen species in the pathophysiology of human reproduction. Fertil Steril. (2003) 79:82943. doi: 10.1016/S0015-0282(02)04948-8

33. Bui AD, Sharma R, Henkel R, Agarwal A. Reactive oxygen species impact on sperm DNA and its role in male infertility. Andrologia. (2018) 50:e13012. doi: $10.1111 /$ and.13012

34. Gürler H, Malama E, Heppelmann M, Calisici O, Leiding C, Kastelic JP, et al. Effects of cryopreservation on sperm viability, synthesis of reactive oxygen species, and DNA damage of bovine sperm. Theriogenology. (2016) 86:562-71. doi: 10.1016/j.theriogenology.2016.02.007

35. Aitken RJ. Impact of oxidative stress on male and female germ cells: implications for fertility. Reproduction. (2020) 159:R189-R201. doi: 10.1530/REP-19-0452

36. Badouard C, Ménézo Y, Panteix G, Ravanat JL, Douki T, Cadet J, et al. Determination of new types of DNA lesions in human sperm. Zygote. (2008) 16:9-13. doi: 10.1017/S0967199407004340

37. Gosálvez J, López-Fernández C, Fernández J, Esteves S, Johnston S. Unpacking the mysteries of sperm DNA fragmentation: Ten frequently asked questions. J Reprod Biotech Fert (2015) 4:1-16. doi: $10.1177 / 2058915815594454$

38. Cand,é C, Vahsen N, Garrido C. (2004) Apoptosis-inducing factor (AIF): caspase-independent after all. Cell Death Differen. (2004) 11:5915. doi: 10.1038/sj.cdd. 4401400

39. Sakkas D, Mariethoz E, John JCS. Abnormal sperm parameters in humans are indicative of an abortive apoptotic mechanism linked to the Fas-mediated pathway. Exp Cell Res. (1999) 251:350-5. doi: 10.1006/excr.1999.4586

40. Sakkas D, Alvarez JG. Sperm DNA fragmentation: mechanisms of origin, impact on reproductive outcome, and analysis. Fertil Steril. (2010) 93:102736. doi: 10.1016/j.fertnstert.2009.10.046

41. Oliva R. Protamines and male infertility. Hum Reprod Update. (2006) 12:417-35. doi: 10.1093/humupd/dml009

42. Bench GS, Friz AM, Corzett MH, Morse DH, Balhorn R. (1996) DNA and total protamine masses in individual sperm from fertile mammalian subjects. Cytometry. 23, 26371. doi: 10.1002/(SICI) 1097-0320(19960401)23:4<263::AID-CYTO1>3.0. $\mathrm{CO} ; 2-\mathrm{I}$

43. Simon L, Castillo J, Oliva R, Lewis SE. Relationships between human sperm protamines, DNA damage and assisted reproduction outcomes. Reprod Biomed Online. (2011) 23:724-34. doi: 10.1016/j.rbmo.2011.08.010

44. Winkle T, Rosenbusch B, Gagsteiger F, Paiss T, Zoller N. The correlation between male age, sperm quality and sperm DNA fragmentation in 320 men attending a fertility center. J Assist Reprod Genet. (2009) 26:416. doi: 10.1007/s10815-008-9277-3

45. Nijs M, De Jonge C, Cox A, Janssen M, Bosmans E, Ombelet W. Correlation between male age, WHO sperm parameters, DNA fragmentation, chromatin packaging and outcome in assisted reproduction technology. Andrologia. (2011) 43:174-9. doi: 10.1111/j.1439-0272.2010.01040.x

46. Vagnini L, Baruffi RLR, Mauri AL, Petersen CG, Massaro FC, Pontes A, et al. The effects of male age on sperm DNA 
damage in an infertile population. Reprod Biomed Online. (2007) 15:514-9. doi: 10.1016/S1472-6483(10)60382-3

47. Belloc S, Benkhalifa M, Junca AM, Dumont M, Bacrie PC, Ménézo Y. Paternal age and sperm DNA decay: discrepancy between chromomycin and aniline blue staining. Reprod Biomed Online. (2009) 19:264-9. doi: 10.1016/S1472-6483(10)60083-1

48. Fortes MR, Holroyd RG, Reverter A, Venus BK, Satake N, Boe-Hansen GB. The integrity of sperm chromatin in young tropical composite bulls. Theriogenology. (2012) 78:326-33 doi: 10.1016/j.theriogenology.201 2.02.007

49. Carreira JT, Trevizan JT, Carvalho IR, Kipper B, Rodrigues LH, Silva C, et al. Does sperm quality and DNA integrity differ in cryopreserved semen samples from young, adult, and aged Nellore bulls? Basic Clin Androl. (2017) 27:12. doi: 10.1186/s12610-017-0056-9

50. Setchell BP, Bergh A, Widmark A, Damber JE. Effect of testicular temperature on vasomotion and blood flow. Int J Androl. (1995) 18:1206. doi: 10.1111/j.1365-2605.1995.tb00397.x

51. Garg A, Kumaresan A, Ansari MR. Effects of hydrogen peroxide $(\mathrm{H} 2 \mathrm{O} 2)$ on fresh and cryopreserved buffalo sperm functions during incubation at $37^{\circ} \mathrm{C}$ in vitro. Reprod Domestic Anim. (2009) 44:90712. doi: 10.1111/j.1439-0531.2008.01115.x

52. Barth AD, Bowman PA. The sequential appearance of sperm abnormalities after scrotal insulation or dexamethasone treatment in bulls. Can Vet J. (1994) 35:93.

53. Silanikove N, Koluman N. Impact of climate change on the dairy industry in temperate zones: predications on the overall negative impact and on the positive role of dairy goats in adaptation to earth warming. Small Rum Res. (2015) 123:27-34. doi: 10.1016/j.smallrumres.2014. 11.005

54. Foote RH, Brockett CC, Kaproth MT. Motility and fertility of bull sperm in whole milk extender containing antioxidants. Anim. Reprod. Sci. (2002) 71:13-23. doi: 10.1016/S0378-4320(02)00018-0

55. Maxwell WM, Stojanov T. Liquid storage of ram semen in the absence or presence of some antioxidants. Reprod Fertil Dev. (1996) 8:101320. doi: 10.1071/RD9961013

56. Funahashi H, Sano T. Select antioxidants improve the function of extended boar semen stored at 10 C. Theriogenology. (2005) 63:160516. doi: 10.1016/j.theriogenology.2004.06.016

57. Jackson RE, Bormann CL, Hassun PA, Rocha AM, Motta EL, Serafini PC, et al. Effects of semen storage and separation techniques on sperm DNA fragmentation. Fertil Steril. (2010) 94:2626-30. doi: 10.1016/j.fertnstert.2010.04.049

58. Gosalvez J, de la Torre J, López-Fernández C, Pérez-Gutiérrez L, Ortega L, Caballero P, et al. DNA fragmentation dynamics in fresh versus frozen thawed plus gradient-isolated human spermatozoa. Syst Biol Reprod Med. (2010) 56:27-36. doi: 10.3109/19396360903515430

59. Rao TKS, Kumar B, Sharma VK, Sriranga KR, Baishya A, Bhakat M, et al. Effect of vaccination on performance of dairy animals with special reference to bulls: a review. Theriogenol Insight Int J Reprod Anim. (2017) 7:18597. doi: 10.5958/2277-3371.2017.00037.7

60. Bhakat M, Mohanty TK, Gupta AK, Chakravarty AK, Singh P, Abdullah M. Effect of $\mathrm{HS}$ and BQ vaccination on semen quality parameters of Murrah buffalo bulls. J Infect Mol Biol. (2015) 3:24-7. doi: 10.14737/journal.jimb/2015/3.24.27

61. Gosálvez J, Vázquez JM, Enciso M, Fernández JL, Gosálbez A, Bridle JR, et al. Sperm DNA fragmentation in rams vaccinated with Miloxan. Open Vet Sci J. (2008) 2:7-10. doi: 10.2174/1874318808002010007

62. Gupta MD, Rathi G, Sontakke SH, Vinod S, Mushtaque M, Kadam H, et al. Effect of foot and mouth disease vaccination on seminal traits in pure Holstein Friesian bulls. Indian J Anim Res. (2018) 52:17703. doi: $10.18805 /$ ijar.B-3445

63. Kjelland ME, González-Marín C, Gosálvez J, López-Fernández C, Lenz RW, Evans KM, et al. DNA fragmentation kinetics and postthaw motility of flow cytometric-sorted white-tailed deer sperm. J Anim Sci. (2011) 89:39964006. doi: 10.2527/jas.2011-4014

64. De Ambrogi M, Spinaci M, Galeati G, Tamanini C. Viability and DNA fragmentation in differently sorted boar spermatozoa. Theriogenology. (2006) 66:1994-2000. doi: 10.1016/j.theriogenology.2006.05.017
65. Gosálvez J, Ramirez MA, López-Fernández C, Crespo F, Evans KM, Kjelland ME, et al. Sex-sorted bovine spermatozoa and DNA damage: II. Dyn Features Theriogenol. (2011) 75:206-11. doi: 10.1016/j.theriogenology.2010.09.011

66. Boe-Hansen GB, Morris ID, Ersbøll AK, Greve T, and Christensen P. DNA integrity in sexed bull sperm assessed by neutral Comet assay and sperm chromatin structure assay. Theriogenology. (2005) 63:1789802 doi: 10.1016/j.theriogenology.2004.08.004

67. Balao da Silva CM, Ortega-Ferrusola C, Morrell JM, Rodriguez Martínez H, Peña FJ. Flow Cytometric chromosomal sex sorting of stallion spermatozoa induces oxidative stress on mitochondria genomic DNA. Reprod Dom Anim. (2016) 51:18-25 doi: 10.1111/rda.12640

68. Prakash MA, Kumaresan A, Manimaran A, Joshi RK, Layek SS, Mohanty TK, et al. Sexing of spermatozoa in farm animals: a mini review. Adv Anim Vet Sci. (2014) 2:226-32. doi: 10.14737/journal.aavs/2014/2.4. 226.232

69. Parrilla I, del Olmo D, Sijses L, Martinez-Alborcia MJ, Cuello C, Vazquez JM, et al. Differences in the ability of spermatozoa from individual boar ejaculates to withstand different semen-processing techniques. Anim Reprod Sci. (2012) 132:66-73. doi: 10.1016/j.anireprosci.2012.04.003

70. Jiménez-Rabadán P, Ramón M, García-Álvarez O, Maroto-Morales A, Del Olmo E, Pérez-Guzmán MD, et al. Effect of semen collection method (artificial vagina vs. electroejaculation), extender and centrifugation on postthaw sperm quality of Blanca-Celtibérica buck ejaculates. Anim Reprod Sci. (2012) 132:88-95. doi: 10.1016/j.anireprosci.2012.04.005

71. Azenabor A, Ekun AO, Akinloye O. Impact of inflammation on male reproductive tract. J Reprod Infert. (2015) 16:123.

72. Zeyad A, Hamad MF, Hammadeh ME. The effects of bacterial infection on human sperm nuclear protamine P1/P2 ratio and DNA integrity. Andrologia. (2017) 50:e12841. doi: 10.1111/and.12841

73. González-Marín C, Roy R, López-Fernández C, Diez B, Carabaño MJ, Fernández JL, et al. Bacteria in bovine semen can increase sperm DNA fragmentation rates: A kinetic experimental approach. Anim Reprod Sci. (2011) 123:139-48. doi: 10.1016/j.anireprosci.2010.11.014

74. Morris ID, Ilott S, Dixon L, Brison DR. The spectrum of DNA damage in human sperm assessed by single cell gel electrophoresis (Comet assay) and its relationship to fertilization and embryo development. Hum Reprod. (2002) 17:990-8. doi: 10.1093/humrep/17.4.990

75. Shamsi MB, Venkatesh S, Pathak D, Deka D, Dada R. Sperm DNA damage \& oxidative stress in recurrent spontaneous abortion (RSA). Indian J Med Res. (2011) 133:550.

76. Zeqiraj A, Beadini S, Beadini N, Aliu H, Gashi Z, Elezaj S, et al. Male Infertility and Sperm DNA Fragmentation. Open Access Maced J Med Sci. (2018) 6:1342-5. doi: 10.3889/oamjms.2018.311

77. Santi D, Spaggiari G, Simoni M. Sperm DNA fragmentation index as a promising predictive tool for male infertility diagnosis and treatment management - meta analyses. (2018) 37:315-26. doi: $10.1016 /$ j.rbmo.2018.06.023

78. Bungum M, Bungum L, Giwercman A. Sperm chromatin structure assay (SCSA): a tool in diagnosis and treatment of infertility. Asian J Androl. (2011) 13:69. doi: 10.1038/aja.2010.73

79. Fernández-Gonzalez R, Moreira PN, Pérez-Crespo M, SánchezMartín M, Ramirez MA, Pericuesta E, et al. Long-term effects of mouse intracytoplasmic sperm injection with DNA-fragmented sperm on health and behavior of adult offspring. Biol Reprod. (2008) 78:761-72. doi: 10.1095/biolreprod.107.065623

80. Aitken RJ, De Iuliis GN, McLachlan RI. Biological and clinical significance of DNA damage in the male germ line. Int J Androl. (2009) 32:4656. doi: 10.1111/j.1365-2605.2008.00943.x

81. Li MW, Lloyd KK. DNA fragmentation index (DFI) as a measure of sperm quality and fertility in mice. Sci Rep. (2020) 10:1-11. doi: 10.1038/s41598-020-60876-9

82. Nallella KP, Sharma RK, Aziz N, Agarwal A. Significance of sperm characteristics in the evaluation of male infertility. Fertil Steril. (2006) 85:629-34. doi: 10.1016/j.fertnstert.2005.08.024

83. Castro LS, Siqueira AFP, Hamilton TRDS, Mendes CM, Visintin JA, Assumpção MEOA. Effect of bovine sperm chromatin integrity evaluated using three different methods on in vitro fertility. Theriogenology. (2018) 107:142-8. doi: 10.1016/j.theriogenology.2017.11.006 
84. Fortes MRS, Satake N, Corbet DH, Corbet NJ, Burns BM, Moore SS, et al. Sperm protamine deficiency correlates with sperm DNA damage in bos indicus bulls. Andrology. (2014) 2:370-8. doi: 10.1111/j.2047-2927.2014.00196.x

85. Kipper BH, Trevizan JT, Carreira JT, Carvalho IR, Mingoti GZ, Beletti ME, et al. Sperm morphometry and chromatin condensation in Nelore bulls of different ages and their effects on IVF. Theriogenology. (2017) 87:15460. doi: 10.1016/j.theriogenology.2016.08.017

86. Didion BA, Kasperson KM, Wixon RL, Evenson DP. Boar fertility sperm chromatin structure status: a retrospective report. J Androl. (2009) 30:65560. doi: 10.2164/jandrol.108.006254

87. Fatehi AN, Bevers MM, Schoevers E, Roelen BAJ, Colenbrander B, Gadella BM. DNA damage in bovine sperm does not block fertilization and early embryonic development but induces apoptosis after the first cleavages. $J$ Androl. (2006) 27:176-88. doi: 10.2164/jandrol.04152

88. O’Donnell L. Mechanisms of spermiogenesis and spermiation and how they are disturbed. Spermatogenesis. (2014) 4:e979623. doi: 10.4161/21565562.2014.979623

89. Zini A, Boman JM, Belzile E, Ciampi A. Sperm DNA damage is associated with an increased risk of pregnancy loss after IVF and ICSI: systematic review and meta-analysis. Hum Reprod. (2008) 23:26638. doi: 10.1093/humrep/den321

90. Brewer L, Corzett M, Lau EY, Balhorn R. Dynamics of protamine 1 binding to single DNA molecules. J Biol Chem. (2003) 278:424038. doi: 10.1074/jbc.M303610200

91. Sotolongo B, Lino E, Ward WS. Ability of hamster spermatozoa to digest their own DNA. Biol Reprod. (2003) 69:202935. doi: 10.1095/biolreprod.103.020594

92. Aoki VW, Emery BR, Liu L, Carrell DT. Protamine levels vary between individual sperm cells of infertile human males and correlate with viability and DNA integrity. $J$ Androl. (2006) 27:890-8. doi: 10.2164/jandrol.106.000703

93. Carreira JT, Trevizan JT, Kipper BH, Perri SHV, Carvalho IR, Rodrigues $\mathrm{LH}$, et al. Impaired protamination and sperm DNA damage in a Nellore bull with high percentages of morphological sperm defects in comparison to normospermic bulls. Arqu Brasil Med Vet Zoot. (2015) 67:41723. doi: 10.1590/1678-7046

94. Dogan S, Vargovic P, Oliveira R, Belser LE, Kaya A, Moura A, et al. Sperm protamine-status correlates to the fertility of breeding bulls. Biol Reprod. (2015) 92:92-91. doi: 10.1095/biolreprod.114.124255

95. Arpanahi A, Brinkworth M, Iles D, Krawetz SA, Paradowska A, Platts AE, et al. Endonuclease-sensitive regions of human spermatozoal chromatin are highly enriched in promoter and CTCF binding sequences. Genome Res. (2009) 19:1338-49. doi: 10.1101/gr.094953.109

96. Hammoud SS, Purwar J, Pflueger C, Cairns BR, Carrell DT. Alterations in sperm DNA methylation patterns at imprinted loci in two classes of infertility. Fertil Steril. (2010) 94:172833. doi: 10.1016/j.fertnstert.2009.09.010

97. Tavalaee M, Razavi S, Nasr-Esfahani MH. Influence of sperm chromatin anomalies on assisted reproductive technology outcome. Fertil Steril. (2009) 91:1119-26. doi: 10.1016/j.fertnstert.2008.01.063

98. Ozmen B, Caglar GS, Koster F, Schopper B, Diedrich K, Al-Hasani S. Relationship between sperm DNA damage, induced acrosome reaction and viability in ICSI patients. Reprod Biomed Online. (2007) 15:20814. doi: 10.1016/S1472-6483(10)60710-9

99. Virro MR, Larson-Cook KL, Evenson DP. Sperm chromatin structure assay (SCSA () ) parameters are related to fertilization, blastocyst development, and ongoing pregnancy in in vitro fertilization and intracytoplasmic sperm injection cycles. Fertil Steril. (2004) 81:1289-95. doi: 10.1016/j.fertnstert.2003.09.063

100. Carrell DT, Liu L. Altered protamine 2 expression is uncommon in donors of known fertility, but common among men with poor fertilizing capacity, and may reflect other abnormalities of spermiogenesis. J Androl. (2001) 22:604-10. doi: 10.1002/j.1939-4640.2001.tb02220.x

101. Rajender S, Avery K, Agarwal A. Epigenetics, spermatogenesis and male infertility. Mutation Res Rev Mutation Res. (2011) 727:62-71. doi: 10.1016/j.mrrev.2011.04.002
102. Urdinguio RG, Bayón GF, Dmitrijeva M, Toraño EG, Bravo C, Fraga MF, et al. Aberrant DNA methylation patterns of spermatozoa in men with unexplained infertility. Hum Reprod. (2015) 30:1014-28. doi: 10.1093/humrep/dev053

103. Biermann K, Steger K. Epigenetics in male germ cells. J Androl. (2007) 28:466-80. doi: 10.2164/jandrol.106. 002048

104. Feinberg AP, Cui H, Ohlsson R. DNA methylation and genomic imprinting: insights from cancer into epigenetic mechanisms. Sem Cancer Biol. (2002) 12:389-98. doi: 10.1016/S1044-579X(02)0 0059-7

105. Payer B, Lee JT. X chromosome dosage compensation: how mammals keep the balance. Annu Rev Genet. (2008) 42:73372. doi: 10.1146/annurev.genet.42.110807.091711

106. Oakes CC, La Salle S, Smiraglia DJ, Robaire B, Trasler JM. Developmental acquisition of genome-wide DNA methylation occurs prior to meiosis in male germ cells. Dev Biol. (2007) 307:368-79. doi: 10.1016/j.ydbio.2007.05.002

107. Hajkova P, Erhardt S, Lane N, Haaf T, El-Maarri O, Reik W, et al. Epigenetic reprogramming in mouse primordial germ cells. Mech Dev. (2002) 117:1523. doi: 10.1016/S0925-4773(02)00181-8

108. Úbeda F, Wilkins JF. Imprinted Genes Human Disease: An Evolutionary Perspective. New York, NY: Springer. (2008) p. 101-15. doi: 10.1007/978-0-387-77576-0_8

109. Poplinski A, Tüttelmann F, Kanber D, Horsthemke B, Gromoll J. Idiopathic male infertility is strongly associated with aberrant methylation of MEST and IGF2/H19 ICR1. Int $J$ Androl. (2010) 33:642-9. doi: 10.1111/j.1365-2605.2009.01000.x

110. Kläver R, Gromoll J. Bringing epigenetics into the diagnostics of the andrology laboratory: challenges and perspectives. Asian J Androl. (2014) 16:669. doi: 10.4103/1008-682X.125412

111. Jena SC, Kumar S, Rajput S, Roy B, Verma A, Kumaresan A, et al. Differential methylation status of IGF2-H19 locus does not affect the fertility of crossbred bulls but some of the CTCF binding sites could be potentially important. $\mathrm{Mol}$ Reprod Dev. (2014) 81:350-62. doi: 10.1002/mrd.22303

112. Chan D, Cushnie DW, Neaga OR, Lawrance AK, Rozen R, Trasler JM. Strainspecific defects in testicular development and sperm epigenetic patterns in 5,10-methylenetetrahydrofolate reductase-deficient mice. Endocrinology. (2010) 151:3363-73. doi: 10.1210/en.2009-1340

113. Khazamipour N, Noruzinia M, Fatehmanesh P, Keyhanee M, Pujol P. MTHFR promoter hypermethylation in testicular biopsies of patients with non-obstructive azoospermia: the role of epigenetics in male infertility. Hum Reprod. (2009) 24:2361-4. doi: 10.1093/humrep/dep194

114. Houshdaran S, Cortessis VK, Siegmund K, Yang A, Laird PW, Sokol RZ. Widespread epigenetic abnormalities suggest a broad DNA methylation erasure defect in abnormal human sperm. PLoS ONE. (2007) 2:e1289. doi: 10.1371/journal.pone.0001289

115. Wang X, Kadarmideen HN. An Epigenome-wide DNA methylation map of testis in pigs for study of complex traits. Front Genet. (2019) 10:405. doi: 10.3389/fgene.2019.00405

116. Li JY, Lees-Murdock DJ, Xu GL, Walsh CP. Timing of establishment of paternal methylation imprints in the mouse. Genomics. (2004) 84:95260. doi: 10.1016/j.ygeno.2004.08.012

117. Kobayashi H, Sato A, Otsu E, Hiura H, Tomatsu C, Utsunomiya T, et al. Aberrant DNA methylation of imprinted loci in sperm from oligospermic patients. Hum Mol Genet. (2007) 16:2542-51. doi: 10.1093/hmg/ ddm 187

118. Kropp J, Carrillo JA, Namous H, Daniels A, Salih SM, Song J, et al. Male fertility status is associated with DNA methylation signatures in sperm and transcriptomic profiles of bovine preimplantation embryos. BMC Genomics. (2017) 18:280. doi: 10.1186/s12864-017-3673-y

119. Tunc O, Tremellen K. Oxidative DNA damage impairs global sperm DNA methylation in infertile men. J Assist Reprod Genet. (2009) 26:53744. doi: 10.1007/s10815-009-9346-2

120. Kitamura A, Miyauchi N, Hamada H, Hiura H, Chiba H, Okae H, et al. Epigenetic alterations in sperm associated with male infertility. Congenit Anom (Kyoto). (2015) 55:133-44. doi: 10.1111/cga.12113 
121. Urrego R, Rodriguez-Osorio N, Niemann H. Epigenetic disorders and altered gene expression after use of assisted reproductive technologies in domestic cattle. Epigenetics. (2014) 9:803-15. doi: 10.4161/epi. 28711

122. Miller D, Brinkworth M, Iles D. Paternal DNA packaging in spermatozoa: more than the sum of its parts? DNA, histones, protamines and epigenetics. Reproduction. (2010) 139:287-301. doi: 10.1530/REP-09-0281

123. El Hajj N, Zechner U, Schneider E, Tresch A, Gromoll J, Hahn T, et al. Methylation status of imprinted genes and repetitive elements in sperm DNA from infertile males. Sex Dev. (2011) 5:60-9. doi: 10.1159/000323806

124. Marques CJ, Costa P, Vaz B, Carvalho F, Fernandes S, Barros A, et al. Abnormal methylation of imprinted genes in human sperm is associated with oligozoospermia. MHR-Basic Sci Reprod Med. (2008) 14:6774. doi: 10.1093/molehr/gam093

125. Pacheco SE, Houseman EA, Christensen BC, Marsit CJ, Kelsey KT, Sigman $\mathrm{M}$, et al. Integrative DNA methylation and gene expression analyses identify DNA packaging and epigenetic regulatory genes associated with low motility sperm. PLoS ONE. (2011) 6:e20280. doi: 10.1371/journal.pone. 0020280

126. Ward WS. Function of sperm chromatin structural elements in fertilization and development. MHR. (2009) 16:30-6. doi: 10.1093/molehr/gap080

127. Güneş S, Kulaç T. The role of epigenetics in spermatogenesis. Turkish J Urol. (2013) 39:181. doi: 10.5152/tud.2013.037

128. Peters AH, O'Carroll D, Scherthan H, Mechtler K, Sauer S, Schöfer C, et al. Loss of the Suv39h histone methyltransferases impairs mammalian heterochromatin and genome stability. Cell. (2001) 107:323-37. doi: 10.1016/S0092-8674(01)00542-6

129. Ait-Si-Ali S, Guasconi V, Fritsch L, Yahi H, Sekhri R, Naguibneva I, et al. A Suv39h-dependent mechanism for silencing S-phase genes in differentiating but not in cycling cells. EMBO J. (2004) 23:60515. doi: 10.1038/sj.emboj.7600074

130. Okada Y, Scott G, Ray MK, Mishina Y, Zhang Y. Histone demethylase JHDM2A is critical for Tnp1 and Prm1 transcription and spermatogenesis. Nature. (2007) 450:119. doi: 10.1038/nature06236

131. Thomas T, Dixon MP, Kueh AJ, Voss AK. Mof (MYST1 or KAT8) is essential for progression of embryonic development past the blastocyst stage and required for normal chromatin architecture. Mol Cell Biol. (2008) 28:5093105. doi: 10.1128/MCB.02202-07

132. Neal KC, Pannuti A, Smith ER, Lucchesi JC. A new human member of the MYST family of histone acetyl transferases with high sequence similarity to Drosophila MOF. Biochim Biophy Acta. (2000) 1490:1704. doi: 10.1016/S0167-4781(99)00211-0

133. Yi J, Luo J. SIRT1 and p53, effect on cancer, senescence and beyond. Biochim Biophys Acta. (2010) 1804:1684-9. doi: 10.1016/j.bbapap.2010.05.002

134. Casas-Mollano JA, Jeong BR, Xu J, Moriyama H, Cerutti H. The MUT9p kinase phosphorylates histone $\mathrm{H} 3$ threonine 3 and is necessary for heritable epigenetic silencing in Chlamydomonas. Proc Natl Acad Sci USA. (2008) 105:6486-91. doi: 10.1073/pnas.0711310105

135. Aihara $\mathrm{H}$, Nakagawa $T$, Yasui $\mathrm{K}$, Ohta $\mathrm{T}$, Hirose $\mathrm{S}$, Dhomae $\mathrm{N}$, et al. Nucleosomal histone kinase-1 phosphorylates H2A Thr 119 during mitosis in the early Drosophila embryo. Genes Dev. (2004) 18:87788. doi: 10.1101/gad.1184604

136. Tachibana M, Nozaki M, Takeda N, Shinkai Y. Functional dynamics of H3K9 methylation during meiotic prophase progression. EMBO J. (2007) 26:3346-59. doi: $10.1038 /$ sj.emboj.7601767

137. Soloaga A, Thomson S, Wiggin GR, Rampersaud N, Dyson MH, Hazzalin $\mathrm{CA}$, et al. MSK2 and MSK1 mediate the mitogen-and stress-induced phosphorylation of histone H3 and HMG-14. EMBO J. (2003) 22:278897. doi: $10.1093 / \mathrm{emboj} / \mathrm{cdg} 273$

138. DeManno DA, Cottom JE, Kline MP, Peters CA, Maizels ET, Hunzicker-Dunn M. Follicle-stimulating hormone promotes histone H3 phosphorylation on serine-10. Mol Endocrinol. (1999) 13:91-105. doi: 10.1210/mend.13.1.0222

139. Baarends WM, Wassenaar E, Hoogerbrugge JW, van Cappellen G, Roest HP, Vreeburg J, et al. Loss of HR6B ubiquitin-conjugating activity results in damaged synaptonemal complex structure and increased crossing-over frequency during the male meiotic prophase. Mol Cell Biol. (2003) 23:115162. doi: 10.1128/MCB.23.4.1151-1162.2003
140. Shiio Y, Eisenman RN. Histone sumoylation is associated with transcriptional repression. Proc Natl Acad Sci USA. (2003) 100:13225-30. doi: 10.1073/pnas.1735528100

141. Godmann M, Auger V, Ferraroni-Aguiar V, Sauro AD, Sette C, Behr R, et al. Dynamic regulation of histone H3 methylation at lysine 4 in mammalian spermatogenesis. Biol Reprod. (2007) 77:754-64. doi: 10.1095/biolreprod.107.062265

142. Sonnack V, Failing K, Bergmann M, Steger K. Expression of hyperacetylated histone H4 during normal and impaired human spermatogenesis. Andrologia. (2002) 34:384-90. doi: 10.1046/j.1439-0272.2002. 00524.x

143. Peserico A, Simone C. Physical and functional HAT/HDAC interplay regulates protein acetylation balance. Biomed Res Int. (2011) 2011. doi: $10.1155 / 2011 / 371832$

144. Lu LY, Wu J, Ye L, Gavrilina GB, Saunders TL, Yu X. RNF8-dependent histone modifications regulate nucleosome removal during spermatogenesis. Dev Cell. (2010) 18:371-84. doi: 10.1016/j.devcel.2010.01.010

145. Narlikar GJ, Fan HY, Kingston RE. Cooperation between complexes that regulate chromatin structure and transcription. Cell. (2002) 108:47587. doi: 10.1016/S0092-8674(02)00654-2

146. Lewis SE, Agbaje I, Alvarez J. Sperm DNA tests as useful adjuncts to semen analysis. Syst Biol Reprod Med. (2008) 54:111-25. doi: 10.1080/19396360801957739

147. Mitchell LA, De Iuliis GN, Aitken RJ. The TUNEL assay consistently underestimates DNA damage in human spermatozoa and is influenced by DNA compaction and cell vitality: development of an improved methodology. Int J Androl. (2011) 34:2-13. doi: 10.1111/j.1365-2605.2009.01042.x

148. Bianchi PG, Manicardi GC, Bizzaro D, Bianchi U, Sakkas D. Effect of deoxyribonucleic acid protamination on fluorochrome staining and in situ nick-translation of murine and human mature spermatozoa. Biol Reprod. (1993) 49:1083-8. doi: 10.1095/biolreprod49. 5.1083

149. Fernández JL, Vázquez-Gundin F, Delgado A, Goyanes VJ, Ramiro-Diaz J, De la Torre J, et al. DNA breakage detection-FISH (DBD-FISH) in human spermatozoa: technical variants evidence different structural features. Mut Res Fundam Mol Mech Mutagenesis. (2000) 453:7782. doi: 10.1016/S0027-5107(00)00079-8

150. Agarwal A, Arafa M, Chandrakumar R, Majzoub A, AlSaid S, Elbardisi H. A multicenter study to evaluate oxidative stress by oxidation-reduction potential, a reliable and reproducible method. Andrology. (2017) 5:93945. doi: 10.1111/andr.12395

151. Evenson DP, Larson KL, Jost LK. Sperm chromatin structure assay: its clinical use for detecting sperm DNA fragmentation in male infertility and comparisons with other techniques. J Androl. (2002) 23:2543. doi: 10.1002/j.1939-4640.2002.tb02599.x

152. Fernández JL, Muriel L, Goyanes V, Segrelles E, Gosálvez J, Enciso M, et al. Simple determination of human sperm DNA fragmentation with an improved sperm chromatin dispersion test. Fertil Steril. (2005) 84:83342. doi: 10.1016/j.fertnstert.2004.11.089

153. Erenpreiss J, Bars J, Lipatnikova V, Erenpreisa J, Zalkalns $§$ JANIS. Comparative study of cytochemical tests for sperm chromatin integrity. $J$ Androl. (2001) 22:45-53. doi: 10.1002/j.1939-4640.2001.tb02152.x

154. Agarwal A, Roychoudhury S, Sharma R, Gupta S, Majzoub A, Sabanegh E. Diagnostic application of oxidation-reduction potential assay for measurement of oxidative stress: clinical utility in male factor infertility. Reprod Biomed Online. (2017) 34:48-57. doi: 10.1016/j.rbmo.2016.10.008

155. Majzoub A, Arafa M, El Ansari W, Mahdi M, Agarwal A, Al-Said S, et al. Correlation of oxidation reduction potential and total motile sperm count: its utility in the evaluation of male fertility potential. Asian J Androl. (2019) 21:1-6. doi: 10.4103/aja.aja_75_19

156. Shen H, Ong C. Detection of oxidative DNA damage in human sperm and its association with sperm function and male infertility. Free Radic Biol Med. (2000) 28:529-36. doi: 10.1016/S0891-5849(99)00234-8

157. Da Costa R, Amaral S, Redmann K, Kliesch S, Schlatt S. Spectral features of nuclear DNA in human sperm assessed by Raman Microspectroscopy: Effects of UV-irradiation and hydration. PLoS ONE. (2018) 13:e0207786. doi: 10.1371/journal.pone.0207786 
158. Benchaib M, Lornage J, Mazoyer C, Lejeune H, Salle B, Guerin JF. Sperm deoxyribonucleic acid fragmentation as a prognostic indicator of assisted reproductive technology outcome. Fertil Steril. (2007) 87:93100. doi: 10.1016/j.fertnstert.2006.05.057

159. Fernandez JL, Muriel L, Rivero MT, Goyanes V, Vazquez R and Alvarez JG. The sperm DNA fragmentation test: a simple method for the determination of sperm DNA fragmentation. J Androl. (2003) 24:59-66.

160. Evgeni E, Charalabopoulos K, Asimakopoulos B. Human sperm DNA fragmentation and its correlation with conventional semen parameters. $J$ Reprod Infert. (2014) 15:2.

161. Manicardi GC, Bianchi PG, Pantano S, Azzoni P, Bizzaro D, Bianchi U, et al. Presence of endogenous nicks in DNA of ejaculated human spermatozoa and its relationship to chromomycin A3 accessibility. Biol Reprod. (1995) 52:864-7. doi: 10.1095/biolreprod52.4.864

162. Tejada RI, Mitchell JC, Norman A, Marik JJ, Friedman S. A test for the practical evaluation of male fertility by acridine orange (AO) fluorescence. Fertil Steril. (1984) 42:87-91. doi: 10.1016/S0015-0282(16)47963-X

163. Golan R, Shochat L, Weissenberg R, Soffer Y, Marcus Z, Oschry Y, et al. Evaluation of chromatin condensation in human spermatozoa: a flow cytometric assay using acridine orange staining. Mol Hum Reprod. (1997) 3:47-54. doi: 10.1093/molehr/3.1.47

164. Zini A, Kamal K, Phang D, Willis J, Jarvi K. Biologic variability of sperm DNA denaturation in infertile men. Urology. (2001) 58:25861. doi: 10.1016/S0090-4295(01)01180-3

165. Barroso G, Morshedi M, Oehninger S. Analysis of DNA fragmentation, plasma membrane translocation of phosphatidylserine and oxidative stress in human spermatozoa. Hum Reprod. (2000) 15:1338-44. doi: 10.1093/humrep/15.6.1338

166. Ostling, Johanson KJ. Microelectrophoretic study of radiation-induced DNA damages in individual mammalian cells. Biochem Biophys Res Commun. (1984) 123:291-8. doi: 10.1016/0006-291X(84)90411-X

167. Singh NP, McCoy MT, Tice RR, Schneider EL. A simple technique for quantitation of low levels of DNA damage in individual cells. Exp Cell Res. (1988) 175:184-91. doi: 10.1016/0014-4827(88)90265-0

168. Gorczyza W, Gong J, Darzynkiewics Z. Detection of DNA strand breaks in individual apoptotic cells by the in-situ terminal deoxynucleotidyl transferase and nick translation assays. Cancer Res. (1993) 53:1945-51.

169. Ribas-Maynou J, García-Peiró A, Fernández-Encinas A, Abad C, Amengual MJ, Prada E, et al. Comprehensive analysis of sperm DNA fragmentation by five different assays: TUNEL assay, SCSA, SCD test and alkaline and neutral Comet assay. Andrology. (2013) 1:715-22. doi: 10.1111/j.2047-2927.2013.00111.x

170. Martínez-Pastor F, Del Rocío Fernández-Santos M, Domínguez-Rebolledo ÁE, Esteso MC, Garde JJ. Biology of Reproduction Group. DNA status on thawed semen from fighting bull: a comparison between the SCD and the SCSA tests. Reprod Dom Anim. (2009) 44:42431. doi: 10.1111/j.1439-0531.2008.01098.x

171. Serafini R, Varner DD, Bissett W Jr, Blanchard TL, Teague SR, Love CC. Sperm DNA quality evaluated by comet assay and sperm chromatin structure assay in stallions after unilateral orchiectomy. Theriogenology. (2015) 84:833-7. doi: 10.1016/j.theriogenology.2015.05.024

172. Castilla JA, Zamora S, Gonzalvo MC. Sperm chromatin structure assay and classical semen parameters: systematic review. Reprod Biomed Online. (2010) 20:114-24. doi: 10.1016/j.rbmo.2009.10.024

173. Drobnis EZ, Johnson MH. Are we ready to incorporate sperm DNAfragmentation testing into our male infertility work-up? A plea for more robust studies. Reproductive BioMedicine Online. (2015) 30:1112. doi: 10.1016/j.rbmo.2014.12.001

174. Karoui S, Díaz C, González-Marín C, Amenabar ME, Serrano M, Ugarte E, et al. Is sperm DNA fragmentation a good marker for field AI bull fertility? J Anim Sci. (2012) 90:2437-49. doi: 10.2527/jas.2011-4492

175. Januskauskas A, Johannisson A, Rodriguez-Martinez H. Assessment of sperm quality through fluorometry and sperm chromatin structure assay in relation to field fertility of frozen-thawed semen from Swedish AI bulls. Theriogenology. (2001) 55:947-61. doi: 10.1016/S0093-691X(01) 00456-3

176. Pena ST, Stone F, Gummow B, Parker AJ, Paris DBBP. Tropical summer induces DNA fragmentation in boar spermatozoa: implications for evaluating seasonal infertility. Reprod Fert Dev. (2019) 31:590601 doi: $10.1071 /$ RD18159

177. Peris SI, Morrier A, Dufour M, Bailey JL. Cryopreservation of ram semen facilitates sperm DNA damage: relationship between sperm andrological parameters and the sperm chromatin structure assay. J Androl. (2004) 25:224-33. doi: 10.1002/j.1939-4640.2004.tb 02782.x

178. Evenson DP. The Sperm Chromatin Structure Assay (SCSA $®$ ) and other sperm DNA fragmentation tests for evaluation of sperm nuclear DNA integrity as related to fertility. Anim Reprod Sci. (2016) 169:5675. doi: 10.1016/j.anireprosci.2016.01.017

179. Irvine DS, Twigg JP, Gordon EL, Fulton N, Milne PA, Aitken RJ. DNA integrity in human spermatozoa: relationships with semen quality. J Androl. (2000) 21:33-44. doi: 10.1002/j.1939-4640.2000.tb03273.x

180. Donnelly ET, Steele EK, McClure N, Lewis SE. Assessment of DNA integrity and morphology of ejaculated spermatozoa from fertile and infertile men before and after cryopreservation. Hum Reprod. (2001) 16:11919. doi: 10.1093/humrep/16.6.1191

181. McQueen DB, Zhang J, Robins JC. Sperm DNA fragmentation and recurrent pregnancy loss: a systematic review and meta-analysis. Fertil Steril. (2019) 112:54-60. doi: 10.1016/j.fertnstert.2019.03.003

182. Waterhouse KE, Haugan T, Kommisrud E, Tverdal A, Flatberg G, Farstad W, et al. Sperm DNA damage is related to field fertility of semen from young Norwegian Red bulls. Reprod Fert Dev. (2006) 18:81788. doi: 10.1071/RD06029

183. Ferreira HN, Ferreira-Silva JC, Rocha JM, Farrás MC, Calixto M, Moura MT, et al. Variable inter-assay estimation of sperm DNA fragmentation in stallions classified as good and bad semen freezers. CryoLetters. (2018) 39:67-71.

184. Hartmann A, Agurell E, Beevers C, Brendler-Schwaab S, Burlinson B, Clay $\mathrm{P}$, et al. Recommendations for conducting the in vivo alkaline Comet assay. Mutagenesis. (2003) 18:45-51. doi: 10.1093/mutage/18.1.45

185. Burlinson B, Tice RR, Speit G, Agurell E, Brendler-Schwaab SY, Collins AR, et al. Fourth International Workgroup on Genotoxicity testing: results of the in vivo Comet assay workgroup. Mut Res Genet Toxicol Environ Mutagenesis. (2007) 627:31-5. doi: 10.1016/j.mrgentox.2006.08.011

186. Simon L, Brunborg G, Stevenson M, Lutton D, McManus J, Lewis SE. Clinical significance of sperm DNA damage in assisted reproduction outcome. Hum Reprod. (2010) 25:1594-608. doi: 10.1093/humrep/deq103

187. Sun JG, Jurisicova A, Casper RF. Detection of deoxyribonucleic acid fragmentation in human sperm: correlation with fertilization in vitro. Biol Reprod. (1997) 56:602-7. doi: 10.1095/biolreprod56.3.602

188. Baskaran S, Agarwal A, Selvam MKP, Finelli R, Robert KA, Iovine C, et al. Tracking research trends and hotspots in sperm DNA fragmentation testing for the evaluation of male infertility: a scientometric analysis. Reprod Biol Endocrinol. (2019) 17:1-13. doi: 10.1186/s12958-019-0550-3

Conflict of Interest: The authors declare that the research was conducted in the absence of any commercial or financial relationships that could be construed as a potential conflict of interest.

Copyright (C) 2020 Kumaresan, Das Gupta, Datta and Morrell. This is an open-access article distributed under the terms of the Creative Commons Attribution License (CC $B Y)$. The use, distribution or reproduction in other forums is permitted, provided the original author(s) and the copyright owner(s) are credited and that the original publication in this journal is cited, in accordance with accepted academic practice. No use, distribution or reproduction is permitted which does not comply with these terms. 